WSRC-TR-2000-00395

\title{
DWPF MACROBATCH 2 MELT RATE TESTS
}

\author{
M. E. Stone \\ D. P. Lambert
}

Westinghouse Savannah River Company Savannah River Site Aiken, SC 29808

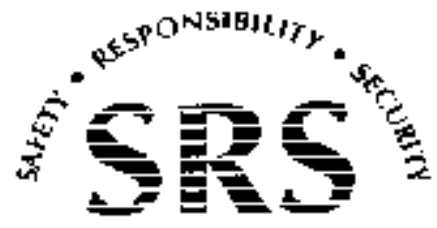

PREPARED FOR THE U.S. DEPARTMENT OF ENERGY UNDER CONTRACT NO. DE-AC09-96SR18500 
This document was prepared in conjunction with work accomplished under Contract No.

DE-AC09-96SR18500 with the U.S. Department of Energy.

\section{DISCLAIMER}

This report was prepared as an account of work sponsored by an agency of the United States Government. Neither the United States Government nor any agency thereof, nor any of their employees, makes any warranty, express or implied, or assumes any legal liability or responsibility for the accuracy, completeness, or usefulness of any information, apparatus, product or process disclosed, or represents that its use would not infringe privately owned rights. Reference herein to any specific commercial product, process or service by trade name, trademark, manufacturer, or otherwise does not necessarily constitute or imply its endorsement, recommendation, or favoring by the United States Government or any agency

thereof. The views and opinions of authors expressed herein do not necessarily state or reflect those of the United States Government or any agency thereof.

This report has been reproduced directly from the best available copy.

Available for sale to the public, in paper, from: U.S. Department of Commerce, National Technical Information Service, 5285 Port Royal Road, Springfield, VA 22161, phone: (800)

553-6847, fax: (703) 605-6900, email: orders@ntis.fedworld.gov online ordering: http://www.ntis.gov/ordering.htm

Available electronically at http://www.doe.gov/bridge

Available for a processing fee to U.S. Department of Energy and its contractors, in paper, from: U.S. Department of Energy, Office of Scientific and Technical Information, P.O. Box 62, Oak Ridge, TN 37831-0062, phone: (865 ) 576-8401, fax: (865) 576-5728, email: reports@ adonis.osti.gov 
Keywords: DWPF

Vitrification,

Bed Expansion

Crucible

Retention: Permanent

\section{DWPF MACROBATCH 2 MELT RATE TESTS}

M. E. Stone

D. P. Lambert

Publication Date: October 5, 2000 


\section{TABLE OF CONTENTS}

1.0 INTRODUCTION ................................................................................................................1

2.0 SUMMARY ...................................................................................................................

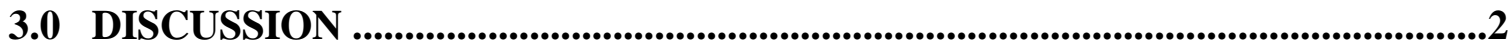

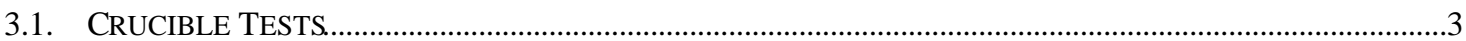

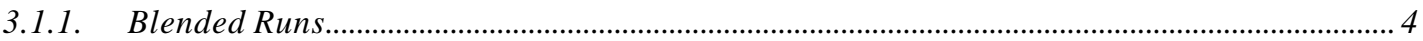

3.1.2. $\quad$ Reduced SRAT Product with Frit 200 ..................................................................................... 5

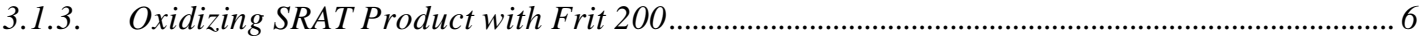

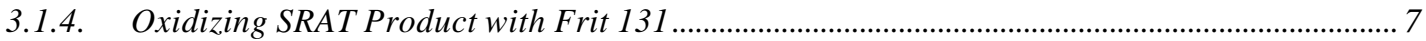

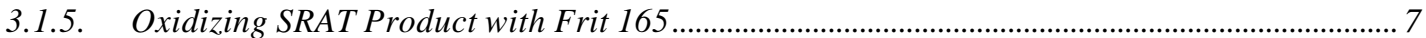

3.1.6. Oxidizing SRAT Product with Frit 202 …............................................................................... 8

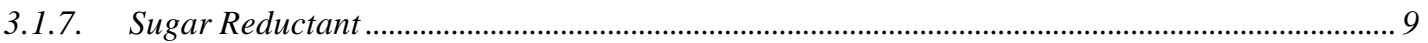

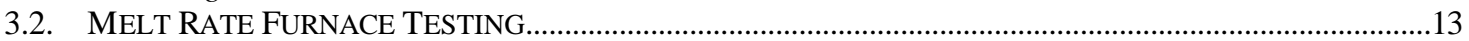

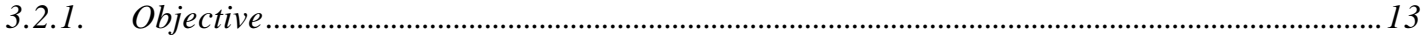

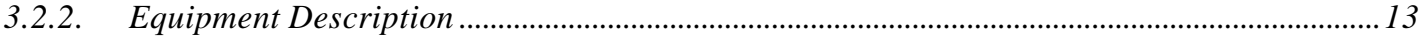

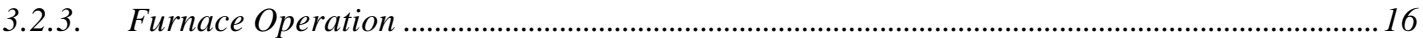

3.2.4. Functional Verification of the Melt Rate Furnace .................................................................... 16

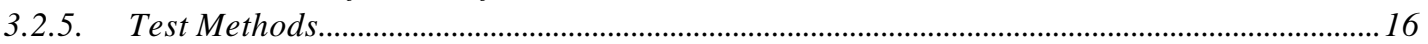

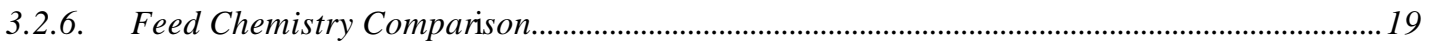

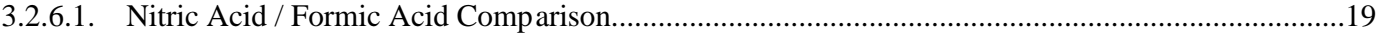

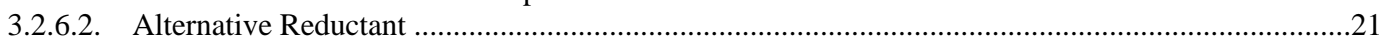

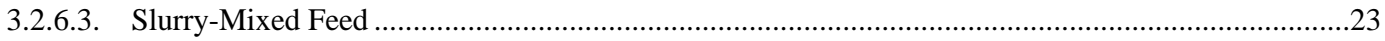

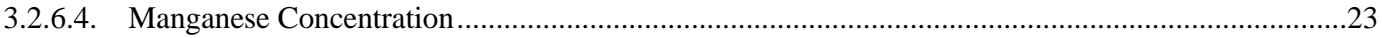

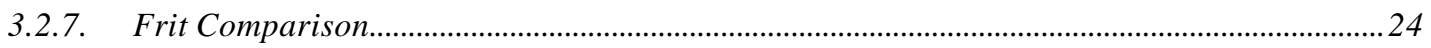

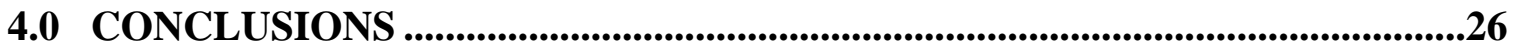

5.0 FUTURE TESTS ..............................................................................................................27

6.0 REFERENCES .................................................................................................................28

\subsection{APPENDIX A: SRAT PRODUCT PREPARATION AND FRIT} COMPOSITIONS .....................................................................................................................29

8.0 APPENDIX B: MELT RATE FURNACE TEMPERATURE CHARTS ............31

9.0 APPENDIX C: PCCS TESTING OF FRITS 165 AND 200 WITH DWPF SRAT

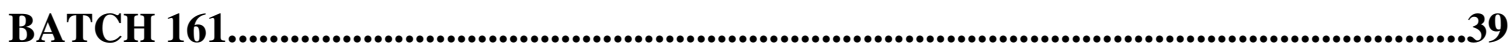


WSRC-TR-2000-00395

Page 1 of 40

\subsection{INTRODUCTION}

The Defense Waste Processing Facility (DWPF) canister production rate must be increased to meet canister production goals. The current flowsheet in DWPF utilizes a combination of nitric acid and formic acid during the melter feed preparation to produce a melter feed with a predicted $\mathrm{Fe}^{+2} / \Sigma \mathrm{Fe}$ ratio of approximately 0.20 . Frit 200 is utilized as the glass former.

Although a number of factors exist that could potentially increase melt rate, this study focused on two: (1) changes in frit composition and (2) changes to the feed preparation process to alter the redox of the melter feed. These two factors were investigated for Macrobatch 2 (sludge batch 1B) utilizing crucible studies and a specially designed "melt rate" furnace. Other potential factors that could increase melt rate include: mechanical mixing via stirring or the use of bubblers, changing the power skewing to redistribute the power input to the melter, and elimination of heat loss (e.g. air inleakage).

\subsection{SUMMARY}

The melt rate testing in FY00 had three primary objectives in trying to determine how to improve the melt rate in DWPF:

1. Develop a tool (melt rate furnace) that can provide the data necessary to allow relative melt rate comparisons.

2. Determine the impact of melter feed processing changes on melt rate.

- Formic acid / nitric acid ratio

- Alternative reductant (e.g., sugar)

3. Determine the impact of frit composition changes on melt rate.

The FY00 testing demonstrated that melt rate can be improved by adding a different frit or producing a much more reducing glass by the addition of sugar as a reductant. The frit that melted the fastest in the melt rate testing was Frit 165 (only previously developed frit compositions were tested during this study). A paper study was performed using the Product Composition Control System (PCCS) to determine the impact on predicted glass viscosity, liquidus, durability, and operating window if the frit was changed from Frit 200 to Frit 165 for Macrobatch 2. PCCS indicated that the window was very similar for both frits. In addition, the predicted viscosity of the frit 165 glass was 46 poise versus 84 poise for the Frit 200 glass. As a result, a change from Frit 200 to Frit 165 is expected to increase the melt rate in DWPF without decreasing waste loading. The data is summarized in Appendix C.

A change to a formic acid only flowsheet would lead to a very small increase in melt rate, based on the tests conducted. The addition of sugar as an additional reductant would lead to a large melt rate increase but would likely create a glass that is too reducing $\left(>0.33 \mathrm{Fe}^{+2} / \Sigma \mathrm{Fe}\right)$ for the DWPF melter. Additional work (e.g. melter offgas flammability, melter feed rheology, and redox correlation) needs to be performed. 
WSRC-TR-2000-00395

Page 2 of 40

The following are the conclusions from the melt rate testing for Macrobatch 2:

- The melt rate furnace is capable of measuring relative melt rate and volume expansion height.

- The melt rate for a given frit composition can be increased significantly by reducing the size of the volume expansion through use of a more effective reductant than formic acid.

- Sugar was more effective than formic acid in reducing volume expansions and improving melt rate, but the glass was more reducing than current DWPF process limits during the limited number of runs where redox was measured.

- Frit composition changes can be used to improve melt rate, with Frit 165 melting the fastest of the four frits tested.

- Changing the ratio of nitric acid to formic acid only slightly increases melt rate.

\subsection{DISCUSSION}

In order to identify ways to improve melt rate, over 150 crucible tests and 17 melt rate furnace tests have been conducted with Macrobatch 2 simulant. The crucible tests, discussed in Section 3.1, were used to provide a basic understanding of the melting process (e.g., identified key temperature ranges where reactions such as decomposition and/or redox shifts occurred that potentially lead to foam formation or a volume expansion). Developing this fundamental understanding provided a tool, which allowed the melt rate furnace results to be interpreted. The melt rate furnace tests, discussed in Section 3.2, were used to compare the melt rate and volume expansions (foaming) of different melter feeds (changes in chemistry and frits to the baseline or nominal sludge-only flowsheet).

Test Methodology

- Melter feed was prepared from Macrobatch 2 (Tank 42) sludge simulant as described in Appendix A.

- Baseline tests were conducted with Frit 200 and melter feed with a redox target of 0.20 $\mathrm{Fe}^{+2} / \Sigma \mathrm{Fe}$.

- Three alternative frits were tested $(131,165$, and 202) to determine if a frit change could be used to improve melt rate. Frit compositions are shown in Appendix A.

- The nitric acid/formic acid ratio was tested at $~ 100 \%$ nitric acid, $25 \%$ nitric acid $/ 75 \%$ formic acid (current DWPF process) and 100\% formic acid to determine if melt rate could be improved by adjusting the ratio of nitric acid to formic acid.

- Sugar was tested as an alternative reductant to formic acid.

The redox target for the melt rate study was predicted based on the models developed for DWPF [4] using the concentration of formate and nitrate in the melter feed. This model was developed using sealed crucibles and was designed to be conservative (overpredict the $\mathrm{Fe}^{+2} / \Sigma \mathrm{Fe}$ ratio) in the prediction of the melter redox. The melt rate furnace and crucibles were not sealed during the testing, therefore the measured redox $\left(\mathrm{Fe}^{+2} / \Sigma \mathrm{Fe}\right.$ ratio) was typically lower than the model predicted. The redox of glass produced by DWPF has not been measured during radioactive operation, therefore the amount of conservatism in the current model has not been determined 
WSRC-TR-2000-00395

Page 3 of 40

and the relationship between the redox of glass produced in the melt rate furnace cannot be compared to the redox of the actual process.

The melt rate furnace tasks were performed in accordance with Task Technical and QA Plan WSRC-RP-2000-00080, in response to Technical Task Request HLW/DWPF/TTR-00-0006. Scoping crucible and gradient furnace tests were conducted per Experimental Plan SRT-PTD2000-00014, Revision 1. The test results were documented in laboratory notebooks WSRC-NB99-00170 and WSRC-NB-2000-0106.

Crucible tests used the following nomenclature: Frit - Melter Feed Type - Temperature - Hold Time, while melt rate furnace (MRF) tests were annotated as: Frit-Melter Feed Type-MRF. The melter feed was annotated as "O" for oxidizing feed, "R" for reducing feed, "B" for blended feed, and "OS" for a run with sugar added, so that a crucible run utilizing Frit 200 and blended feed at $800^{\circ} \mathrm{C}$ for two hours would be "200-B-800-2". "-R" was added to the end of the number if a melt rate furnace run was repeated. All figures in this report utilize this same notation.

\subsection{Crucible Tests}

The crucible tests were conducted to compare melting behavior with different frits and feed redox. Two types of dried melter feed were prepared: oxidizing feed which used mostly nitric acid with only enough formic acid to reduce manganese during the SRAT cycle and reducing feed which utilized only formic acid, as described in Appendix A. "Blended" batches were prepared by combining the oxidizing and reducing sludge to create a melter feed with approximately the same redox as the current DWPF flowsheet. An alternative reductant to replace formic acid was tested by adding sugar to oxidizing sludge batches.

Frit was not added during the preparation of the sludge in order to test four different frits: 131, 165,200 , and 202. The dried SRAT product was ground with a mortar and pestle, then passed through a \#10 sieve prior to mixing with the frit. Grinding the SRAT product finer than \#10 mesh was not possible due to moisture remaining in the SRAT product after drying to "tackiness". The large size of the SRAT product particles impacted the tests, but the relative results should remain the same.

Each run was batched separately with the required amounts of frit and feed (targeted waste loading was $25 \%$, based on the current DWPF flowsheet). Crucible tests were conducted in 100$\mathrm{ml}$ alumina crucibles targeting 45 grams of glass. Based on gradient furnace tests [1], the crucible tests were conducted over a temperature range of $600^{\circ} \mathrm{C}$ to $850^{\circ} \mathrm{C}$ in $50^{\circ}$ intervals with one and two hour hold times at each temperature. Blended runs were conducted with hold times of one, two, four, six, and eight hours at each temperature.

The crucibles were charged with feed material and covered (but not sealed), placed into a furnace at room temperature, heated to setpoint, held at setpoint for the specified amount of time, then quenched in air. The tare weight and initial batch height were measured prior to firing. After firing, the weight of the crucible was measured, then the crucible was sectioned. After sectioning, the final batch height was measured along with the maximum height the batch reached as determined by the residue on the crucible walls. 
WSRC-TR-2000-00395

Page 4 of 40

\subsubsection{Blended Runs}

The melting behavior of the current DWPF batch flowsheet was evaluated by blending highly oxidizing feed with reducing feed to target the same redox $(0.20)$ as the current DWPF flowsheet. Fusing of the frit began at approximately $600^{\circ} \mathrm{C}$ and became more pronounced as the temperature increased to $700^{\circ} \mathrm{C}$. Very little porosity was noted in this temperature range and very little interaction between the frit and SRAT product was noted, as shown in Figure 1. The volume of the batch decreased slightly at $700^{\circ} \mathrm{C}$ with the batch slumped in the center and pulled away from the walls of the crucible.

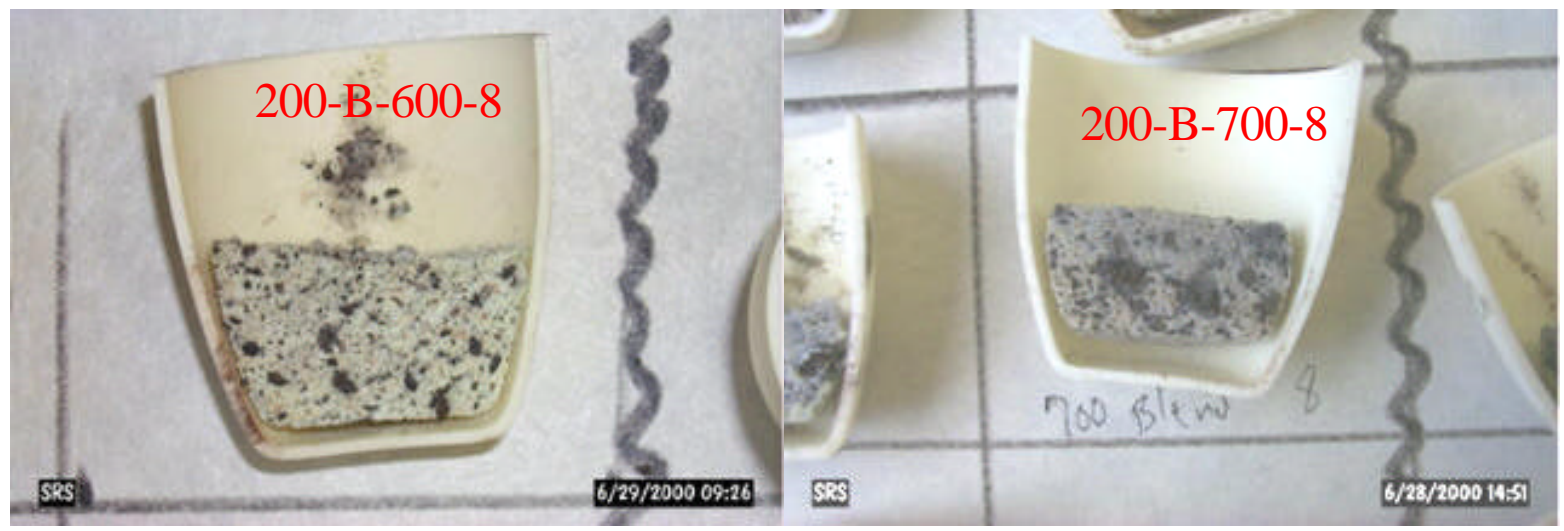

Figure 1 Representative Crucibles from $600-700^{\circ} \mathrm{C}$ Range

The transformation to glass (e.g., formation of an initial liquid phase) was initially detected at $750^{\circ} \mathrm{C}$ as the frit and the SRAT product began to interact. A volume expansion occurred as the batch melted, reaching a peak between 750 and $800^{\circ} \mathrm{C}$, as shown in Figure 2. Nitrate decomposition and manganese reduction can occur in this temperature region and are the two probable sources of the gas trapped during the volume expansion. At $800^{\circ} \mathrm{C}$, the expansion had peaked and a highly porous, purple glass pool had begun to form. Historically, a purple glass has indicated that the manganese in the glass is highly oxidized. The porosity of the melt pool decreased slowly as the hold time increased.

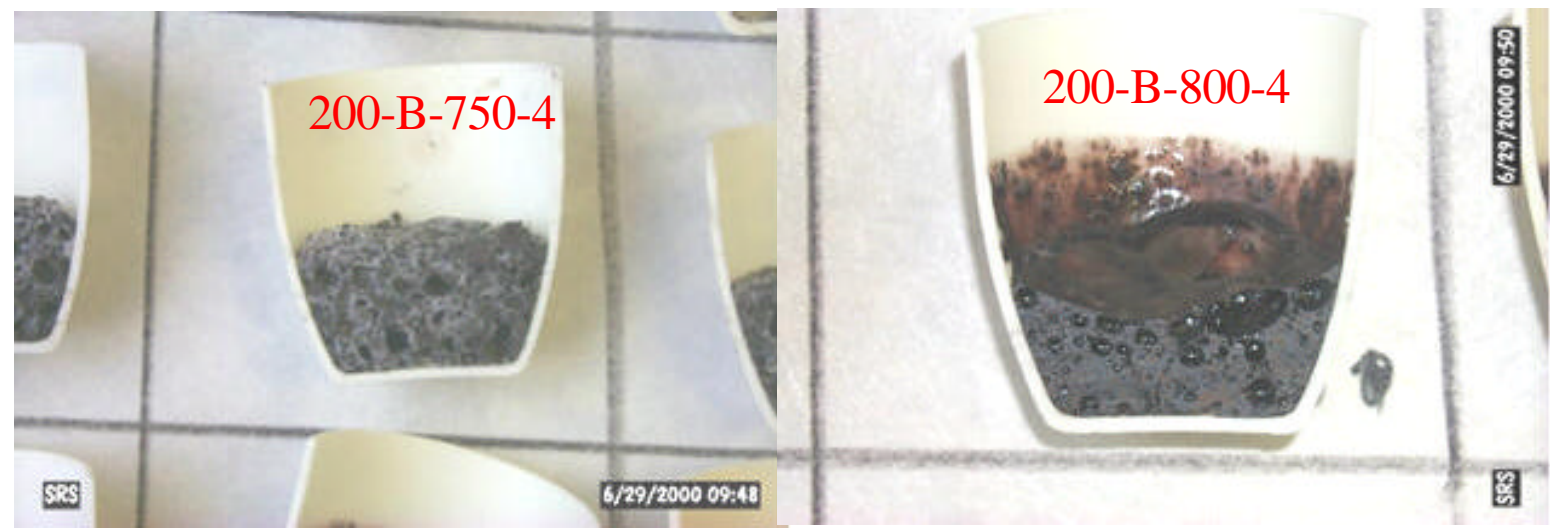

Figure 2. Representative Crucibles From 750 to $800^{\circ} \mathrm{C}$. 
The porosity of the melt pool continued to decrease at temperatures above $800^{\circ} \mathrm{C}$, but bubbles were noted in all tests. As shown in Figure 3, tests conducted at higher temperatures had higher maximum volumes, perhaps due to the higher rate of temperature increase during the volume expansion and collapse for the hotter runs.

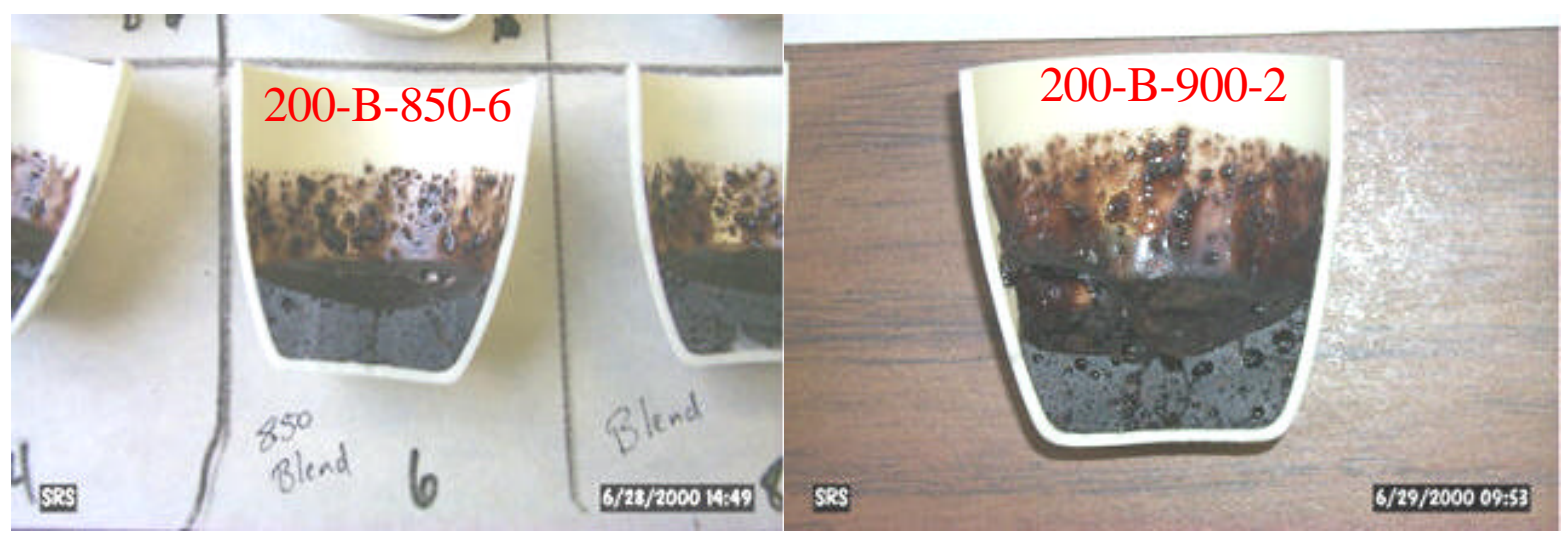

Figure 3. Representative Crucibles From 850 to $900^{\circ} \mathrm{C}$.

\subsubsection{Reduced SRAT Product with Frit 200}

Reducing SRAT product was prepared as described in Appendix A and mixed with Frit 200 to produce reduced melter feed. The melting behavior of the reduced melter feed was significantly different from the blended runs (previously discussed in Section 3.1.1). The onset of melting and foam collapse was delayed approximately $50^{\circ} \mathrm{C}$ and the expansion during melting was significantly reduced, as shown in Figure 4. The volume reduction noted at $700^{\circ} \mathrm{C}$ with the nominal DWPF flowsheet began at $650^{\circ} \mathrm{C}$ with the reduced flowsheet. The expansion of the batch peaked at $750^{\circ} \mathrm{C}$ and the bed slumped very little at $800^{\circ} \mathrm{C}$ from the peak volume at $750^{\circ} \mathrm{C}$. Significant incorporation of the SRAT product into the frit did not occur until $850^{\circ} \mathrm{C}$, when a green-black glass pool was formed with less porosity than the blended runs. A green-black glass pool has historically indicated that the glass is reducing. 
WSRC-TR-2000-00395

Page 6 of 40

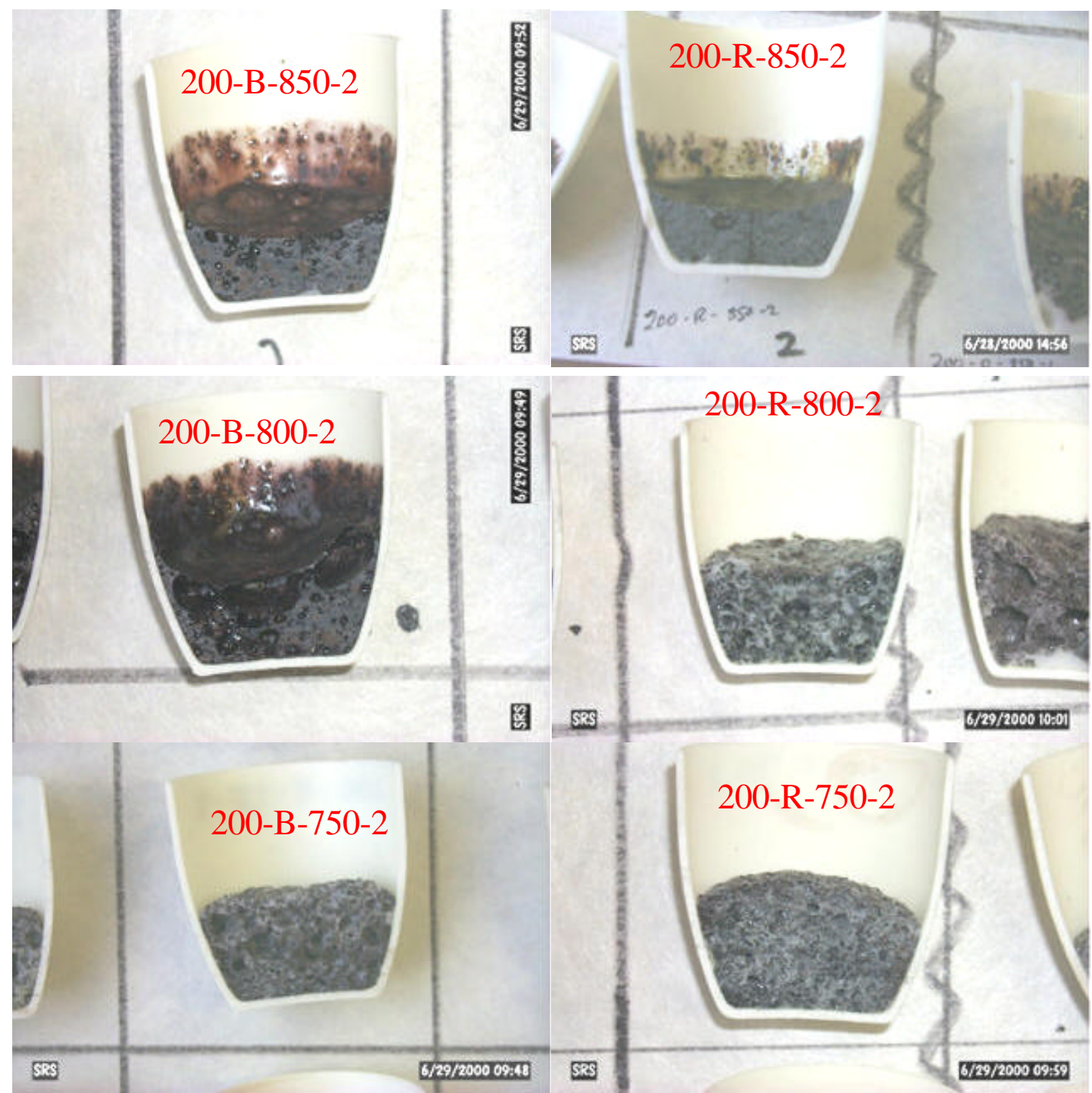

Figure 4. Comparison of Blended Feed to Reducing Feed.

\subsubsection{Oxidizing SRAT Product with Frit 200}

The melting behavior exhibited by the oxidizing feed was very similar to the blended runs. All transformations occurred in the same temperature ranges and the bed expansions and porosity were only slightly increased from the blended runs, as shown in Figure 5. The amount of nitrate in the batch was greatly increased in comparison to the blended runs, but the bed expansion was only marginally higher. 
WSRC-TR-2000-00395

Page 7 of 40
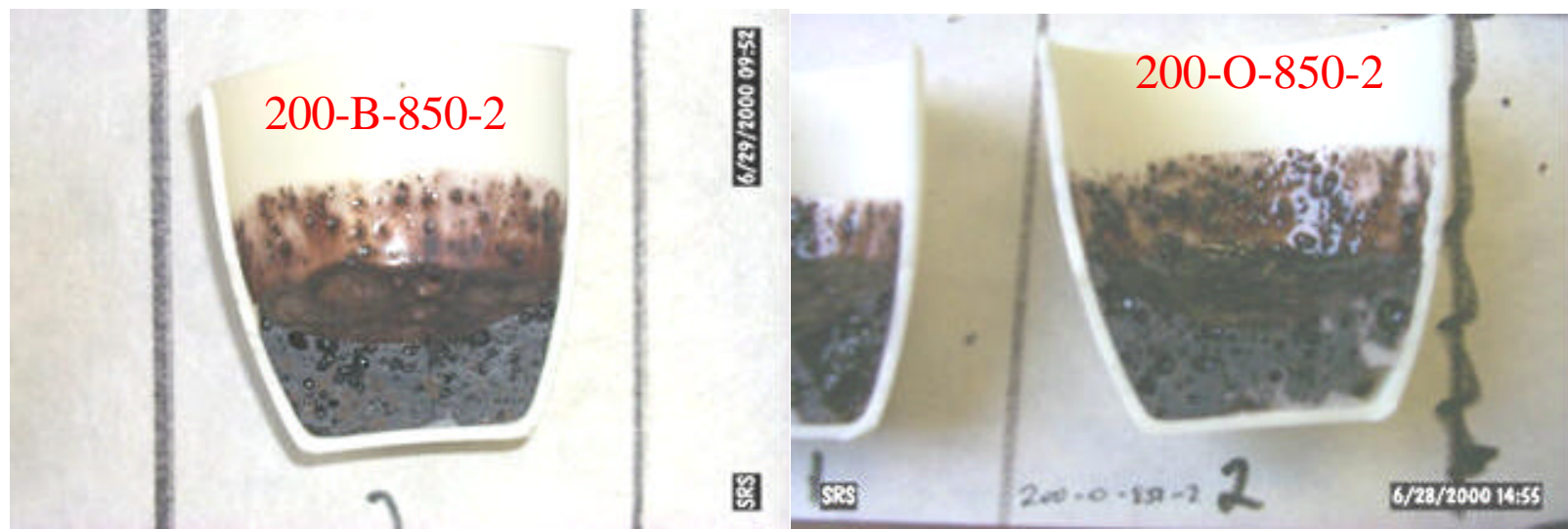

Figure 5. Comparison of Blended Feed to Oxidizing Feed at $850^{\circ} \mathrm{C}$ after 2 hours .

\subsubsection{Oxidizing SRAT Product with Frit 131}

Fusing of the frit was more pronounced at $600^{\circ} \mathrm{C}$ with Frit 131 due to its lower melting point (e.g., higher alkali concentration relative to Frit 200). The transformation to glass began at $700^{\circ} \mathrm{C}$ with Frit 131 versus $750^{\circ} \mathrm{C}$ with Frit 200 and the volume expansion during melting was greatly increased, as shown in Figure 6. If nitrate decomposition is the initiator of the volume expansion, the greater amount of overlap in the melting point of Frit 131 with the temperature range for nitrate decomposition would result in increased expansions. The expansions noted during processing with Frit 131 exceeded the volume of the crucible. The Frit 131-based glass produced after the expansion contained less porosity than runs with Frit 200 with the same temperature and hold time.

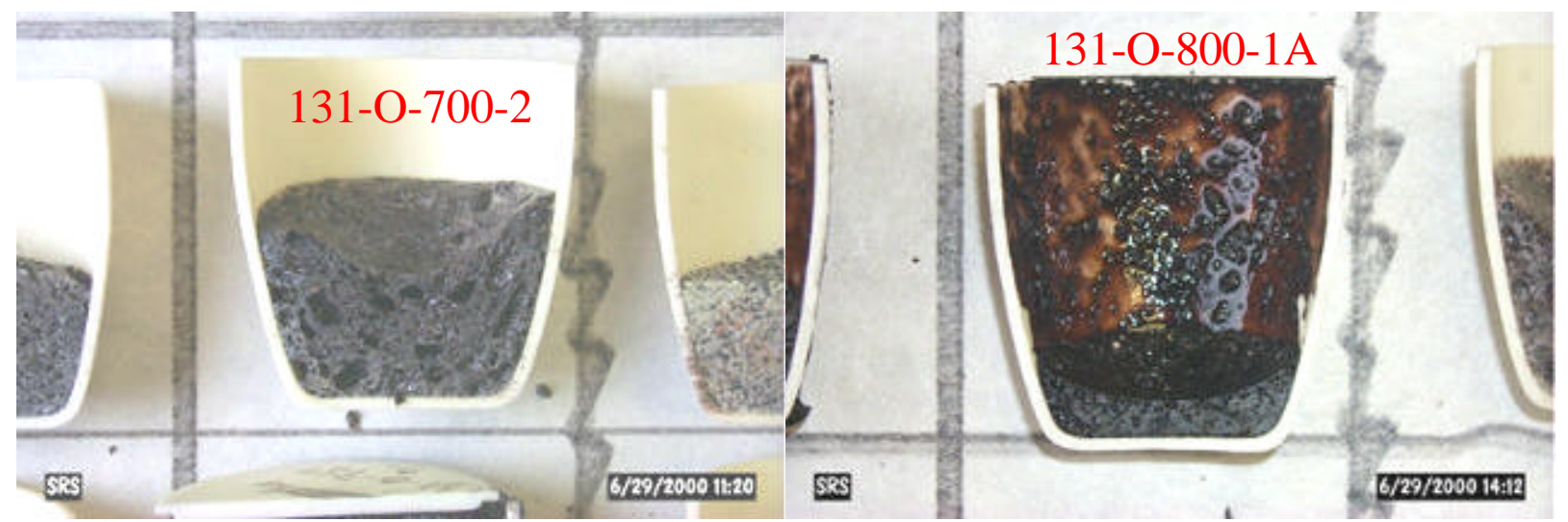

Figure 6. Oxidizing SRAT Product with Frit 131.

\subsubsection{Oxidizing SRAT Product with Frit 165}

The onset of the batch to glass transformation occurred in the same temperature region (750 to $800^{\circ} \mathrm{C}$ ) with Frit 165 as Frit 200. As shown in Figure 7, the volume expansion that occurred as 
WSRC-TR-2000-00395

Page 8 of 40

the batch melted was higher with Frit 165 than Frit 200 and the glass contained more porosity after melting with equal temperature and hold times.

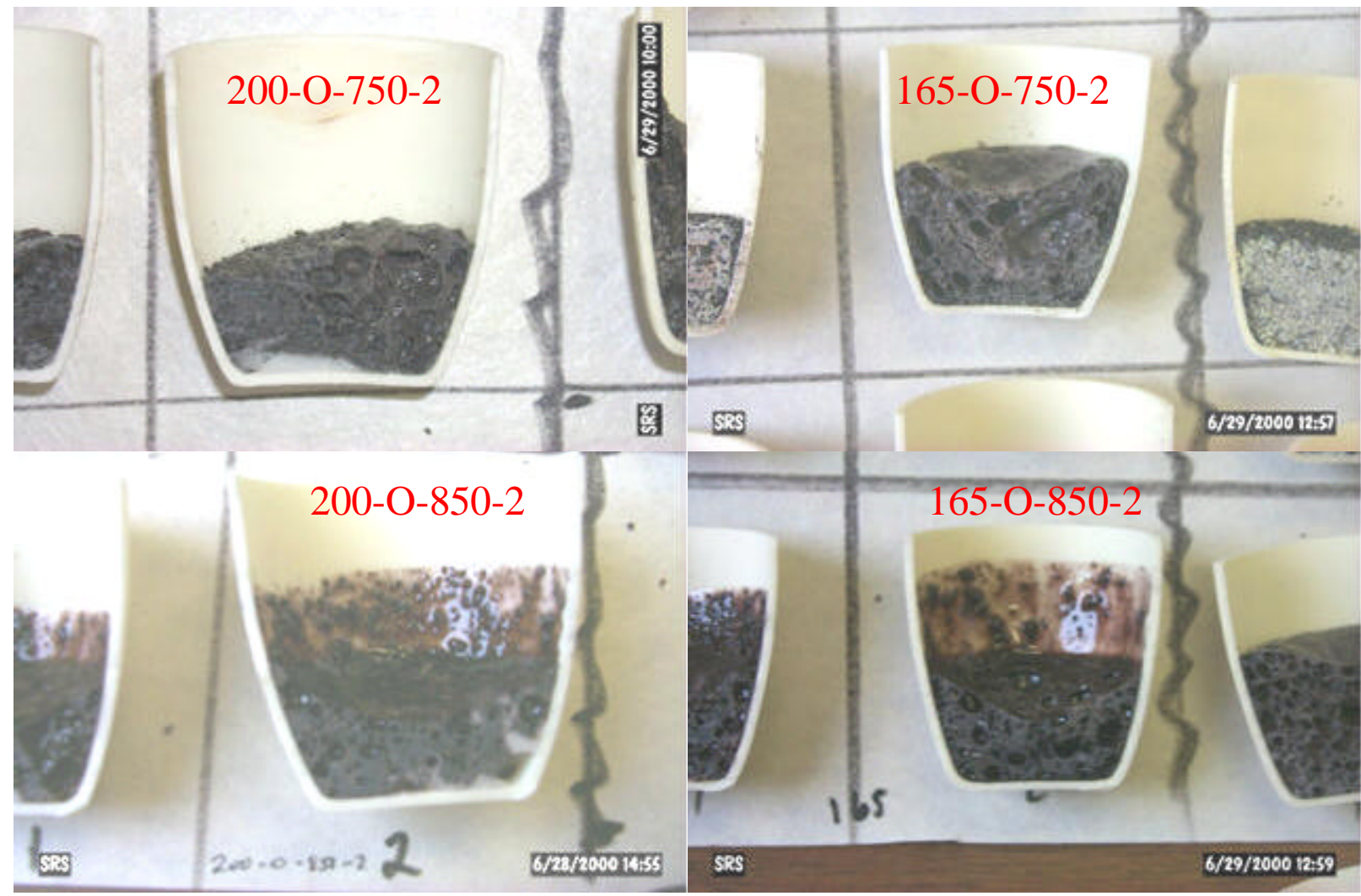

Figure 7. Comparison between Frit 165 and Frit 200 with Oxidizing Sludge.

\subsubsection{Oxidizing SRAT Product with Frit 202}

Frit 202 is more refractory than the other frits due to its higher ( $77 \mathrm{wt} \%$ versus $70 \mathrm{wt} \%)$ silica content. The sintering process began at approximately $800^{\circ} \mathrm{C}$ and transformation to glass began at $850^{\circ} \mathrm{C}$. The volume expansion during melting was more severe than with Frit 200 with a peak at $900^{\circ} \mathrm{C}$, as shown in Figure 8 . The porosity was not significantly diminished after a two hour hold at $900^{\circ} \mathrm{C}$. 
WSRC-TR-2000-00395

Page 9 of 40

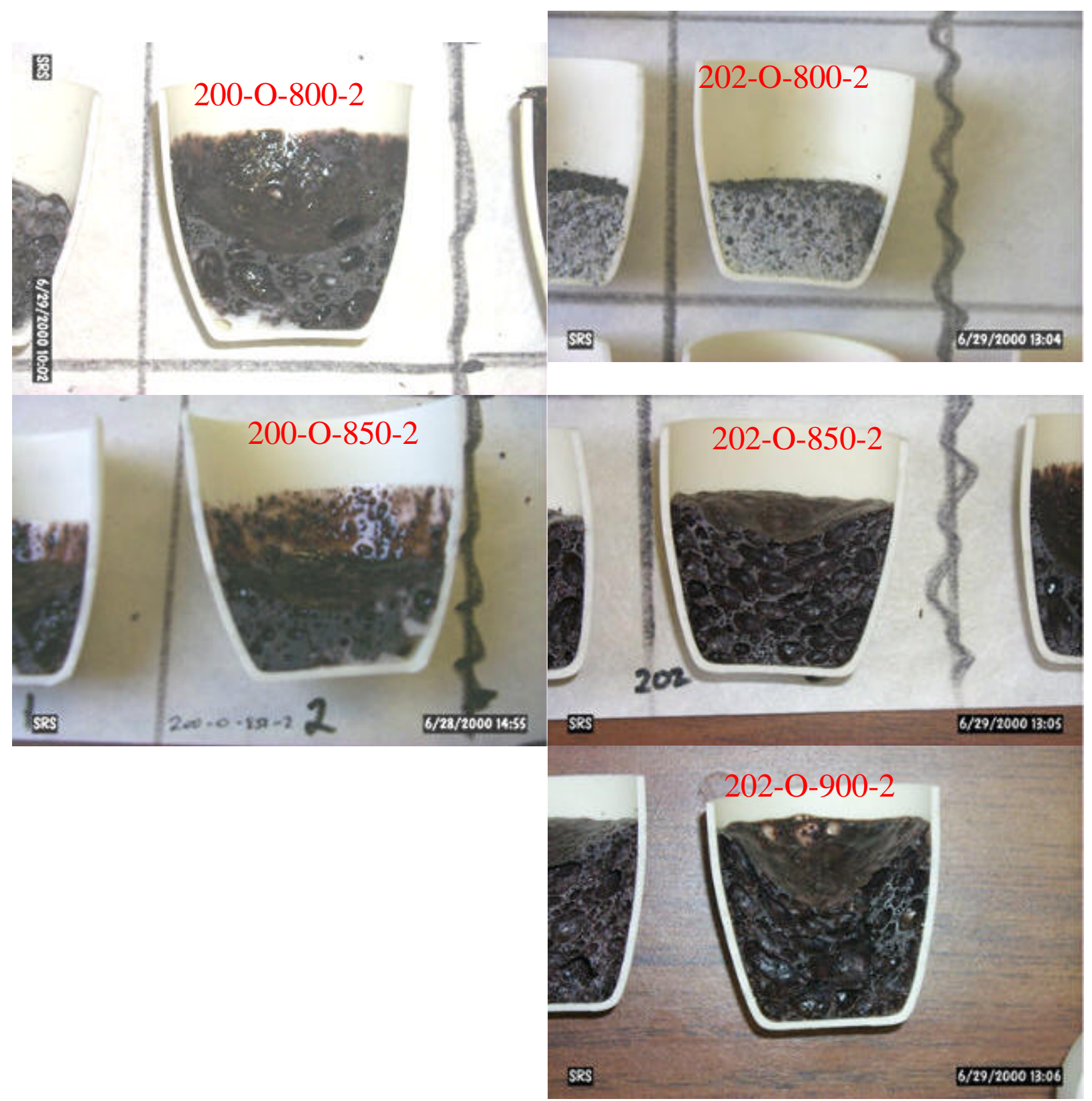

Figure 8. Comparison between Frit 202 and Frit 200 with Oxidizing Sludge.

\subsubsection{Sugar Reductant}

Sugar (sucrose) was utilized to determine if an alternative reductant to formic acid would be more effective at reducing the volume expansion and improving melt rate. Sugar was selected as the alternative reductant based on a literature review of available reductants such as silicon metal, graphite, activated carbon, and urea. Sugar was utilized at West Valley in radioactive vitrification and is being considered for use in the Hanford River Protection Plan vitrification process. 
WSRC-TR-2000-00395

Page 10 of 40

The initial runs were conducted utilizing the oxidizing sludge, Frit 200 and 1.25 grams of sugar per 45 grams of glass. The sugar amount during the initial runs was based on the amount of formate in the blended batch and a 2:1 ratio of carbon from formate to carbon from sugar (based on a carbon valence of +2 in formate and 0 in sugar). The melting behavior was very similar to runs with oxidizing feed, but the volume expansions were slightly increased by the sugar addition (see Figure 9).

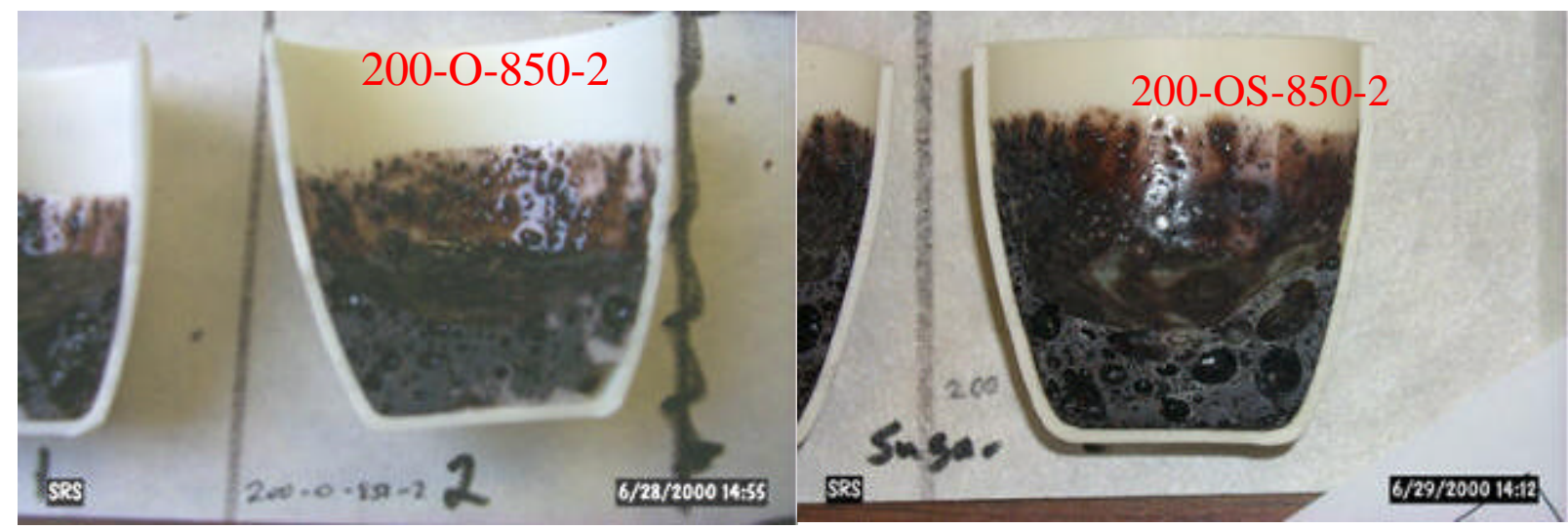

Figure 9. Comparison of Initial Sugar Runs to Oxidizing Feed

Additional tests were then conducted with Frit 202 to determine the amount of sugar required to properly reduce the batch and minimize the volume expansions. 2.5 grams ( $2 \mathrm{X}$ the initial calculated requirement) and 3.75 grams (3X) were added to 45 gram (glass basis) batches and heated to $650^{\circ} \mathrm{C}$. The surface was scratched, and the $2 \mathrm{X}$ batch was found to be mostly white (unreduced) while the $3 \mathrm{X}$ batch was blackened (extremely reduced). The crucibles were then fired to $900^{\circ} \mathrm{C}$. The $2 \mathrm{X}$ run had a volume expansion that was slightly reduced from runs with Frit 202 and oxidizing feed, but the $3 \mathrm{X}$ batch showed almost no expansion and the batch formed a melt pool after firing at $900^{\circ} \mathrm{C}$ for 2 hours, as shown in Figure 10. Almost no expansion was noted in subsequent tests with Frit 131 and Frit 165 using 3.75 grams of sugar. A series of tests was then conducted with $1.5 \mathrm{X}, 2.25 \mathrm{X}, 2.5 \mathrm{X}$, and $2.75 \mathrm{X}$ the initial calculated amount of sugar. The tests were conducted with oxidizing feed and Frit 202, except for the tests with 1.25 grams of sugar, which was conducted with Frit 200. The results are shown in Table 1.

Table 1. Volume Expansion Versus Sugar Amounts (Frit 202 and oxidizing feed).

\begin{tabular}{|c|c|l|}
\hline Ratio to Initial Amount & Sugar Amount & Result \\
\hline 1.00 & 1.25 grams & Expansion worse than oxidizing run \\
\hline 1.50 & 1.88 grams & Expansion worse than oxidizing run \\
\hline 2.00 & 2.50 grams & Slight Improvement versus oxidizing run \\
\hline 2.25 & 2.81 grams & Slight Improvement versus oxidizing run \\
\hline 2.50 & 3.13 grams & Expansion nearly eliminated \\
\hline 2.75 & 3.44 grams & Expansion eliminated \\
\hline 3.00 & 3.75 grams & Expansion eliminated \\
\hline & & \\
\hline
\end{tabular}




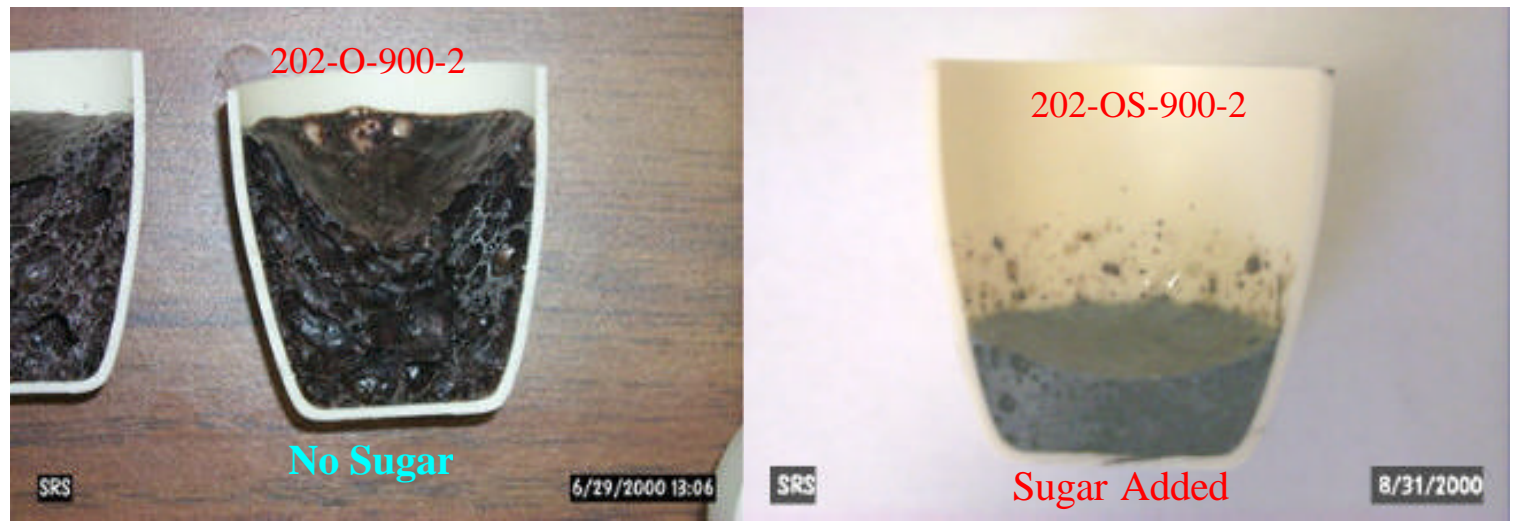

Figure 10. Comparison of Runs with Frit 202 and oxidizing feed

The amount of sugar required to reduce the nitrate in the oxidizing sludge was then calculated based on nitrate sample results for the dried oxidizing sludge and the following equation:

$$
4 \mathrm{~N}^{+5}+5 \mathrm{C}^{0} \rightarrow 2 \mathrm{~N}_{2}^{0}+5 \mathrm{C}^{+4}
$$

The calculated value of 3.14 grams per 45 grams of glass very closely matches the 3.13 grams experimental result. The required amount of sugar, the predicted $\mathrm{Fe}^{+2} / \Sigma \mathrm{Fe}$ ratio, and the carbon content of the melter feed were then calculated for different blends of oxidizing and reducing sludge, as shown in Table 2. The runs were conducted with Frit 200 and targeted 45 grams of glass. No significant volume expansions were noted during the runs.

\section{Table 2. Sugar Addition Calculations}

\begin{tabular}{|c|c|c|c|c|}
\hline $\begin{array}{c}\text { Ratio of Oxidizing } \\
\text { Sludge to } \\
\text { Reducing Sludge }\end{array}$ & $\begin{array}{c}\text { Required Amount of } \\
\text { Sugar for 45 grams } \\
\text { of Glass }\end{array}$ & $\begin{array}{c}\text { Predicted Carbon } \\
\text { Content (TOC) in } \\
\text { Melter Feed }\end{array}$ & $\begin{array}{c}\text { Predicted } \\
\mathrm{Fe}^{+2} / \Sigma \text { Fe } \\
\text { ratio }\end{array}$ & $\begin{array}{c}\text { Measured } \\
\mathrm{Fe}^{+2} / \Sigma \text { Fe } \\
\text { ratio }\end{array}$ \\
\hline $100: 0$ & 3.14 grams & $11,200 \mathrm{ppm}$ & 0.14 & 0.67 \\
\hline $75: 25$ & 2.44 grams & $10,700 \mathrm{ppm}$ & 0.20 & 0.64 \\
\hline $50: 50$ & 1.74 grams & $10,200 \mathrm{ppm}$ & 0.26 & 0.80 \\
\hline $25: 75$ & 1.032 grams & $9,700 \mathrm{ppm}$ & 0.32 & 0.66 \\
\hline $0: 100$ & 0.33 grams & $9,200 \mathrm{ppm}$ & 0.38 & 0.51 \\
\hline
\end{tabular}

Experimental results, also shown in Table 2 indicated that the redox prediction was not accurate when sugar is added to the feed. The redox prediction was calculated based on the following equation, based on the current model for predicting the redox of DWPF glass [4]:

$$
\mathrm{Fe}^{+2} / \Sigma \mathrm{Fe}=0.217+0.253[\mathrm{C}: \mathrm{F}]-0.793[\mathrm{~N}]+0.506[\mathrm{C}: \mathrm{S}]
$$

Where: $\quad[\mathrm{C}: \mathrm{F}]=$ moles of carbon from formate

$[\mathrm{N}]=$ moles of nitrate

$[\mathrm{C}: \mathrm{S}]=$ moles of carbon from sugar 
WSRC-TR-2000-00395

The redox prediction model is based on empirical results from tests with varying formic acid/nitric acid ratios. The model takes into account the fact that formic acid decomposes early in the melting process, therefore it underpredicts the redox for sugar, since sugar does not vaporize at low temperatures in the cold cap. A new model for redox prediction will be required if an alternative reductant is to be used in the DWPF process.

The redox as a function of sugar addition was determined for oxidizing sludge using covered crucibles. The tests were performed with Frit 200 and targeted 45 grams of glass. The results are shown in Table 3. The results indicate that addition of sugar did not impact the redox of the glass until 2.5 grams of sugar was added. The redox of the glass increased very rapidly once the sugar began to overcome the oxidizing tendency of the nitrate in the feed. Only three data points were measured during this region, and two of the points do not match expected trends, therefore further tests will be required to determine a correlation for the redox as a function of sugar quantity.

Table 3. Redox of Oxidizing Sludge as a Function of Sugar Added

\begin{tabular}{|c|c|}
\hline Amount of Sugar Added (Grams) & Measured $\mathrm{Fe}^{+2} / \Sigma$ Fe ratio \\
\hline 0 & $<0.03$ \\
\hline 1.25 & $<0.03$ \\
\hline 1.75 & $<0.03$ \\
\hline 2.25 & $<0.03$ \\
\hline 2.5 & 0.51 \\
\hline 2.75 & 0.23 \\
\hline
\end{tabular}


WSRC-TR-2000-00395

Page 13 of 40

\subsection{Melt Rate Furnace Testing}

\subsubsection{Objective}

The melt rate furnace testing had three objectives:

1. Determine if the melt rate furnace can provide the data necessary to allow relative melt rate comparisons to be made.

2. Determine the impact of melter feed redox changes on melt rate.

- Formic acid / nitric acid ratio

- Alternative reductant (e.g. sugar)

3. Determine the impact of frit composition changes on melt rate.

\subsubsection{Equipment Description}

The melt rate furnace was designed by Denny Bickford and fabricated at Clemson University. The furnace was modified at TNX to support the melt rate tests. The furnace was heated by two 1925 Watt plate heaters and had a one cubic foot inner chamber surrounded by five to 6 inches of ceramic fiber insulation, as shown in Figure 11. The top of the furnace had a 4.5" diameter hole through the insulation. A $1200 \mathrm{ml}$ stainless steel beaker was inserted into the hole so that the top flange of the beaker was nearly flush with the top of the furnace and the bottom of the beaker was nearly flush with the top of the heated chamber, as shown in Figure 11. The top flange of the beaker was larger than the hole, therefore the beaker hung suspended from the top flange. A 1 " thick insulation board was placed over the beaker to prevent excessive heat loss out the top.

The furnace was controlled by a digital pulse relay controller and a type $\mathrm{K}$ thermocouple along the sidewall of the furnace. The type $\mathrm{K}$ thermocouples inserted into the beaker, shown in Figure 12 , were connected to a temperature indicator that logs the readings every 15 seconds. The four lower thermocouples in the beaker were 0.040 " in diameter and were positioned around a $3 / 4$ " radius from the center of the beaker, as shown in Figure 13. The upper thermocouple was 5" above the bottom of the beaker to measure the vapor space temperature. This thermocouple was $1 / 8$ " in diameter and was located at the center of the beaker. An offgas hood was utilized to pull an air sweep across the top of the furnace.

The furnace was designed to heat the bottom of the beaker while insulating the sides and top. This creates a vertical temperature profile in the beaker similar to the one dimensional heat transfer from the glass pool to the cold cap. 
WSRC-TR-2000-00395

Page 14 of 40

Figure 11. Melt Rate Furnace

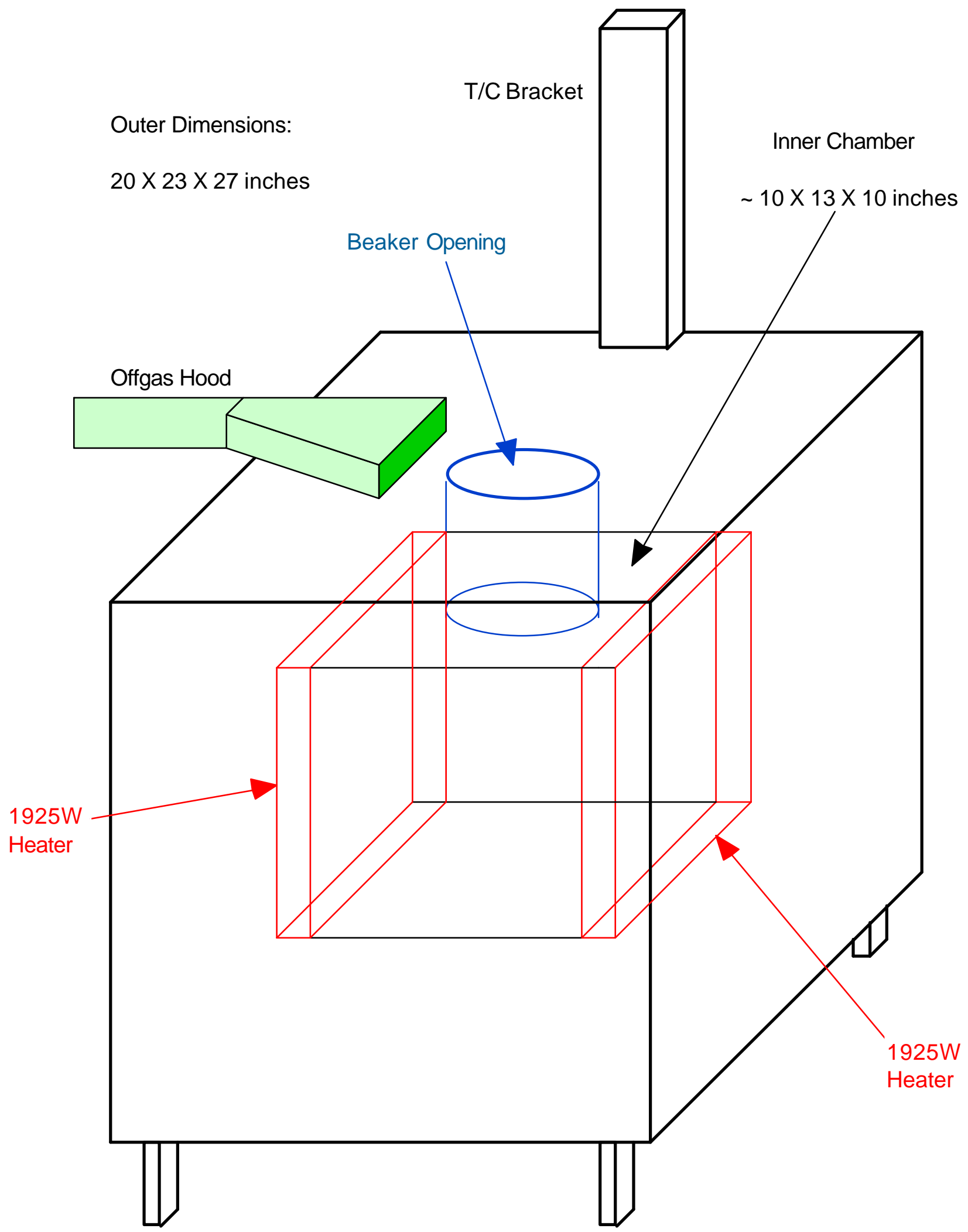


WSRC-TR-2000-00395

Page 15 of 40

Figure 12. Melt Rate Furnace Beaker Instrumentation and Batch Level

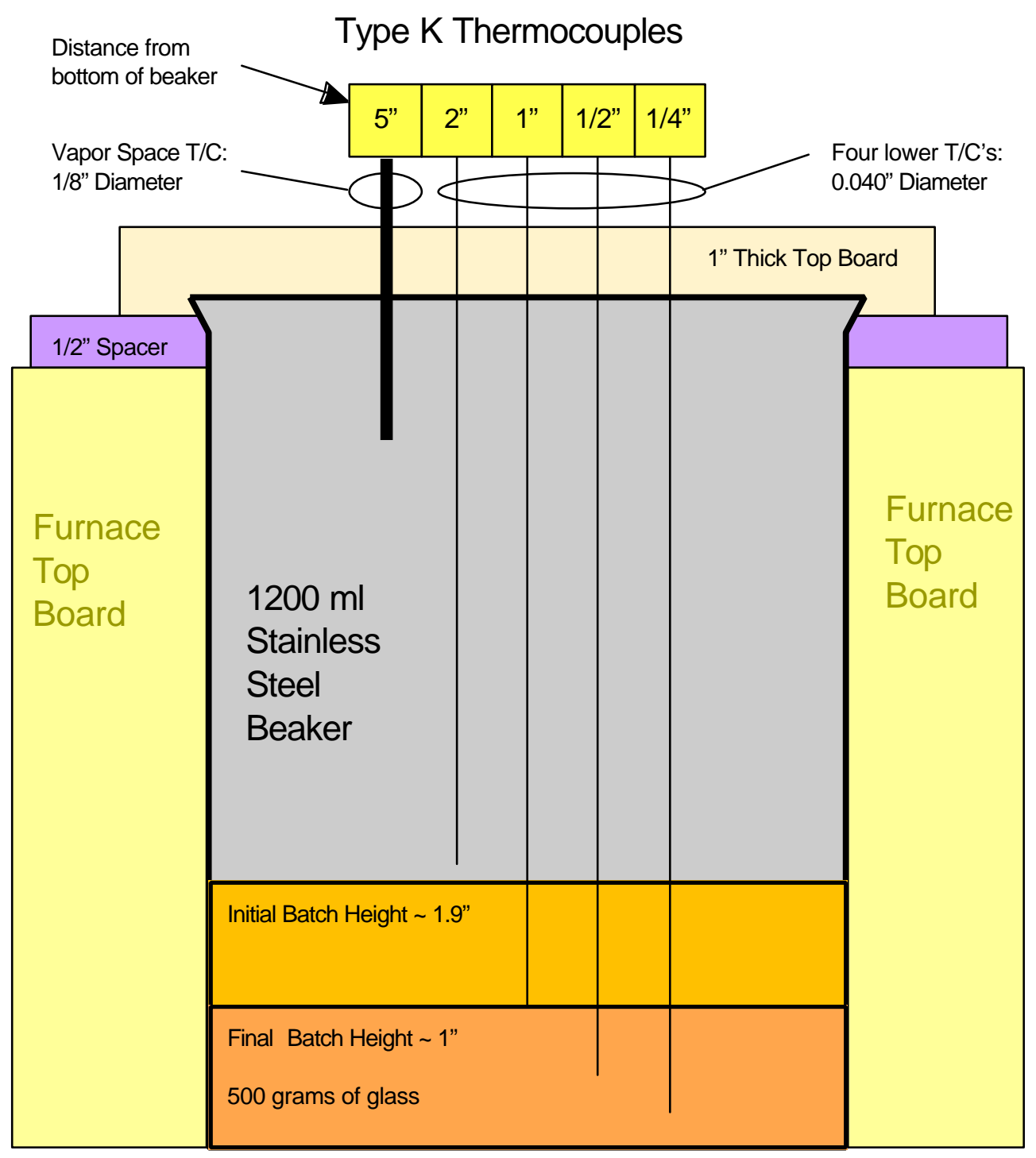

Furnace Chamber: 1150 Degrees Celsius

Figure 13. Position of Thermocouples, Top View

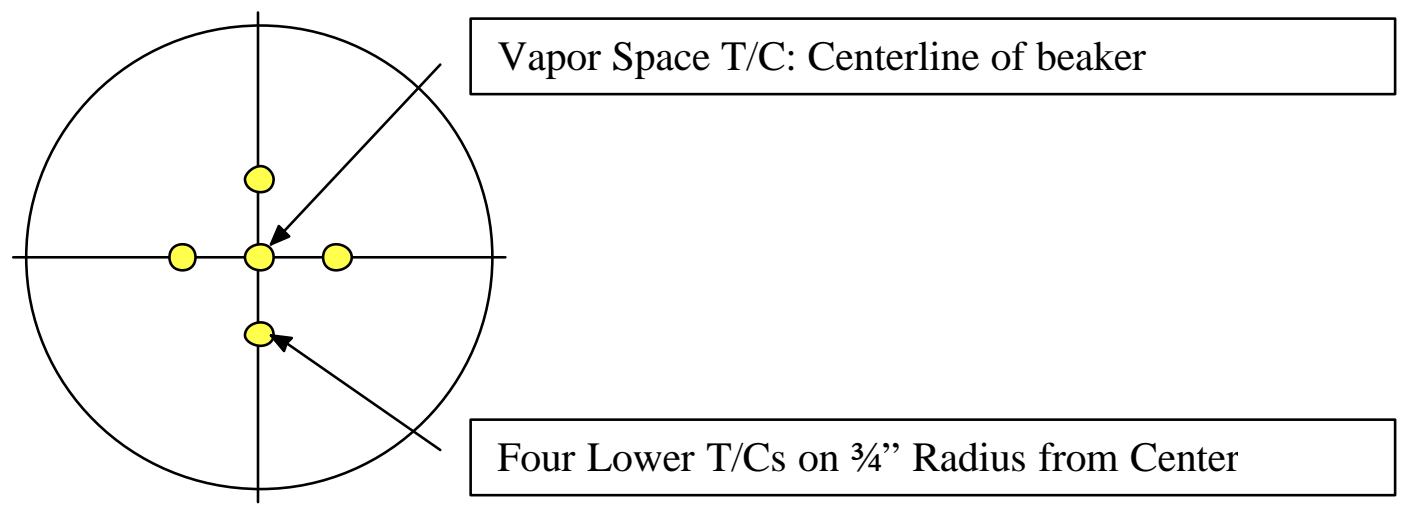


WSRC-TR-2000-00395

Page 16 of 40

\subsubsection{Furnace Operation}

The melt rate furnace is heated to setpoint $\left(1150^{\circ} \mathrm{C}\right)$ with an insulating plug inserted into the top hole. The plug prevents the insulation surrounding the hole from becoming hot during the heatup to prevent heating the sides of the beaker after insertion. The batch is charged to the beaker and the four lower thermocouples installed in the beaker prior to insertion of the beaker into the furnace. Once the furnace reaches setpoint, the plug is removed and the instrumented beaker is inserted. The beaker vapor space thermocouple is then installed and temperature readings are taken every 15 seconds until the beaker is removed. When "steady-state" conditions are reached and the vapor space thermocouple reaches $800^{\circ} \mathrm{C}$, the beaker is removed from the furnace and allowed to cool.

\subsubsection{Functional Verification of the Melt Rate Furnace}

The furnace was initially tested with Frit 200 and Frit 131 without SRAT product. These tests verified the furnace could quickly heat a batch of material to temperature and that the heat transfer rate from the furnace to the beaker would not be the limiting factor during melt rate tests. The initial tests with frit only were conducted with 1000 gram batches and the furnace was capable of melting the frit in 20 minutes. In comparison, the fastest melting rate for frit and feed combined was 500 grams of glass in 35 minutes.

As will be discussed, the initial melt rate furnace tests confirmed that the difference in melt rate between different melter feeds (different frits and reducing agents) was sufficiently large and could be detectable by the melt rate furnace via monitoring temperature as a function of height. The amount of time required to melt a 500 gram batch varied from 35 minutes to greater than 2 hours. The differences in the temperature profile among runs was also discernable by the melt rate furnace and the temperature profile along with the T/C locations enabled the estimation of the size of the volume expansion.

\subsubsection{Test Methods}

Tests in the melt rate furnace resulted in two types of data: the time / temperature data from the thermocouples during the run and physical data from inspection of the beaker contents after the run was complete. The data were used to determine the melt rate and maximum volume expansion for each run. Sufficient duplication of runs has not been performed to permit estimation of the error in the melt rate determination. However, the differences between the measured melt rates for certain melter feeds are large enough that the measurement error should not affect the relative results.

The temperature profile from runs with frit only were very smooth, as shown in Figure 14. During runs with frit and feed, a considerable amount of spiking was observed in the temperature data, as shown in Figure 15. The spiking was caused by foam rising and falling around the thermocouple(s). The foam from a volume expansion is an excellent insulator, therefore thermocouples above the foam are insulated from the heat source and the thermocouples below 
WSRC-TR-2000-00395

Page 17 of 40

the foam are insulated from the heat sink. Once the temperature plot smooth out, steady state conditions are assumed to be reached.

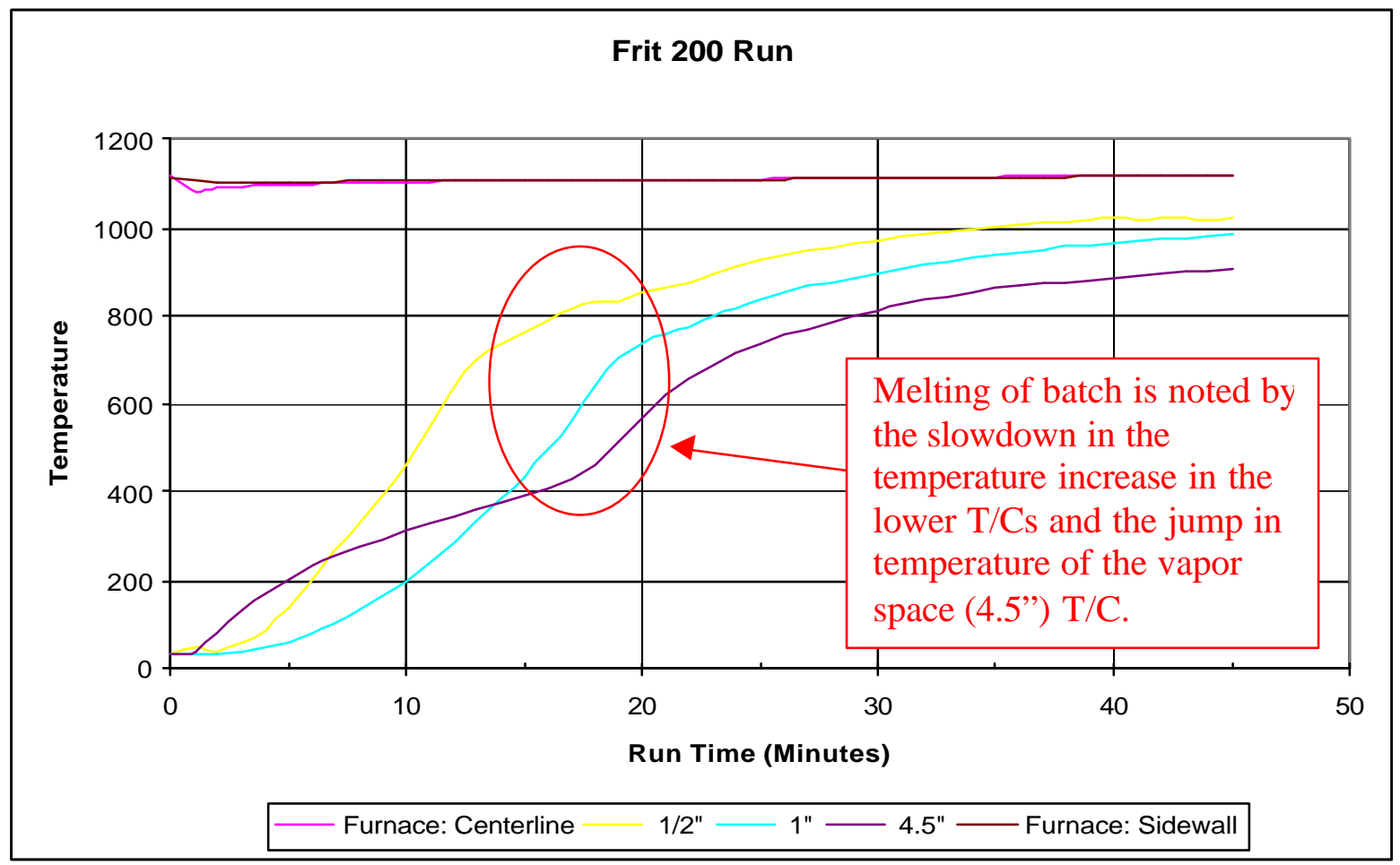

Figure 14. Temperature Profile: Frit 200 Only

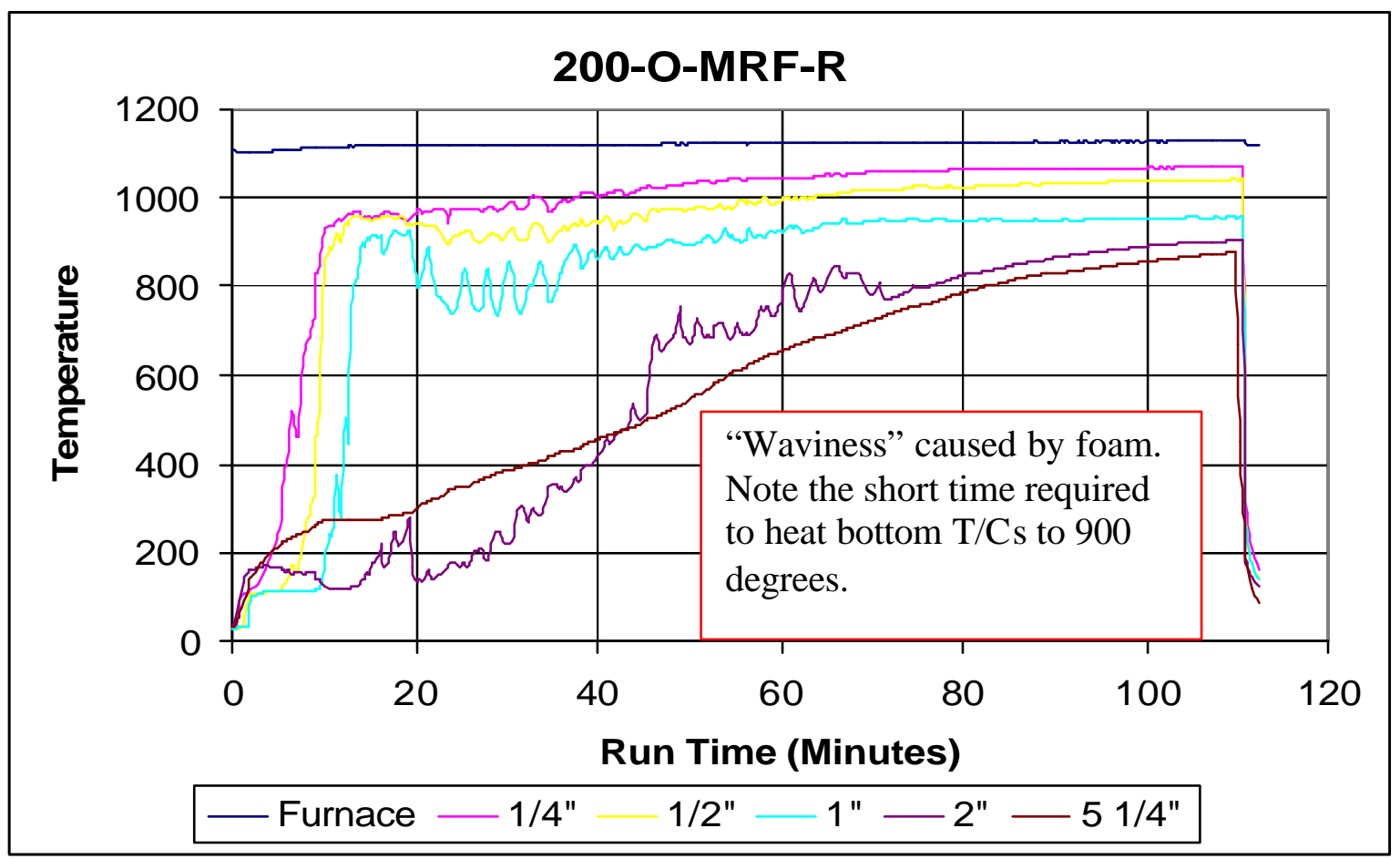

Figure 15. Temperature Profile: Frit 200 and Oxidizing Sludge 
WSRC-TR-2000-00395

Page 18 of 40

The differences between Figure 15, Figure 16, and Figure 17 illustrate how volume expansions affected the temperature profile during the runs. The height of the expansion was estimated by determining which thermocouples were affected by foam. The spikes in the temperatures in Figure 15 indicate that the volume expansion had covered all thermocouples except the vapor space thermocouple approximately 15 minutes into the run. The large temperature difference between the 1" and 2" thermocouples and the "waviness" indicate that the 2" T/C was only partially covered by the expansion. The absence of the spikes in Figure 16 indicate that the expansion did not cover the 2" T/C, while the large spike in Figure 17 indicates that the foam completely covered the 2 " T/C.

The data indicates that the run with sugar had the smallest expansion of the three runs (Figure 16), while the run with Frit 165 had the biggest expansion (Figure 17). Note that the spike in the 2" T/C at 20 minutes is caused by cold material around the T/C collapsing into the melt pool, allowing the T/C to reach equilibrium with the vapor space (Figure 16).

Two indications were used to indicate that the volume expansion had subsided: 1) The vapor space thermocouple reaches $800^{\circ} \mathrm{C}$ and 2) The "waviness" in the temperature readings subsides. The vapor space temperature indication is useful because it indicates that the glass pool is no longer covered with an insulating layer while the smooth temperature increase indicates that foam is not actively rising and falling in the beaker. The temperature profiles for all runs are shown in Appendix B.

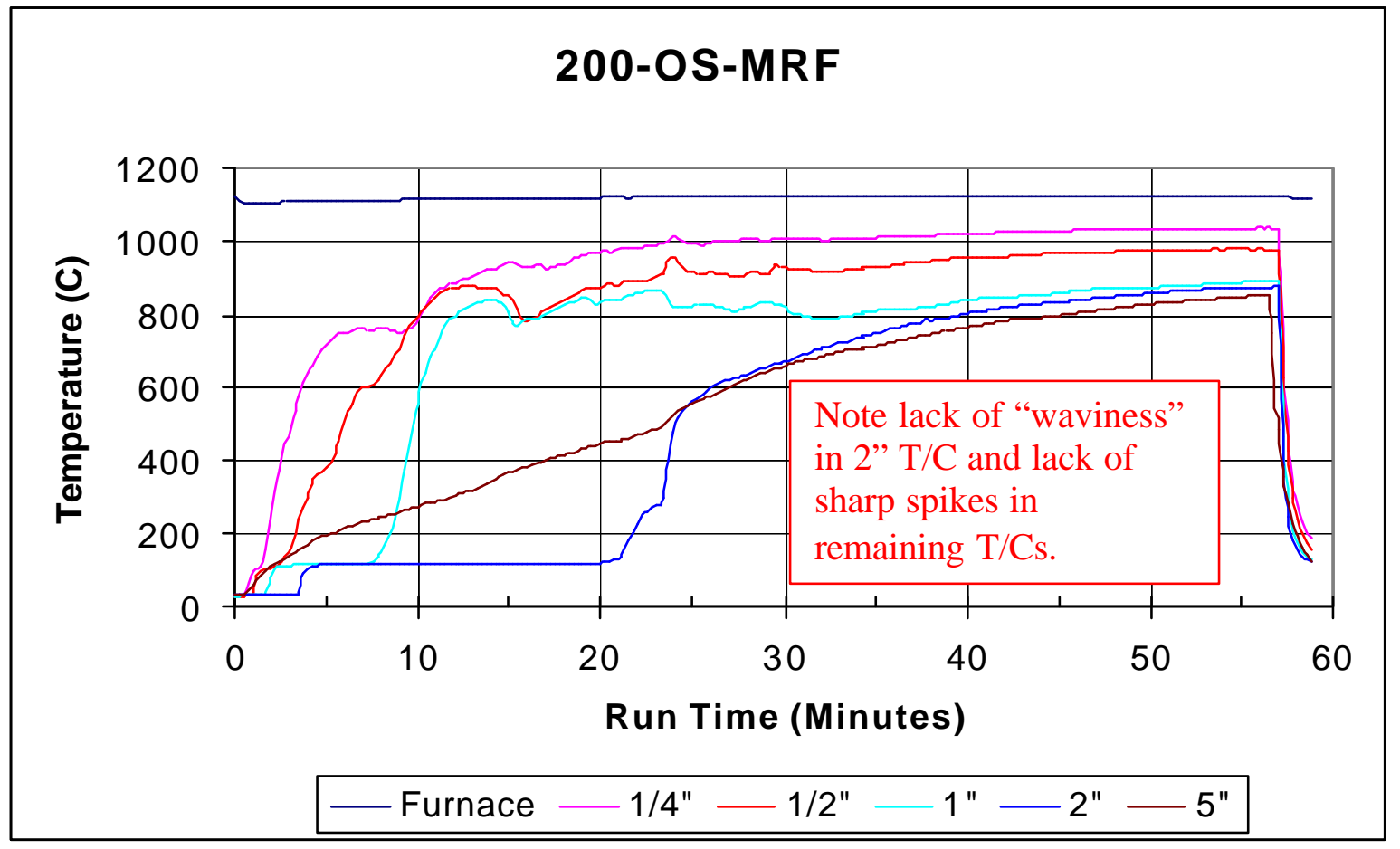

Figure 16. Temperature Profile: Frit 200 and Oxidizing Sludge with Sugar Reductant 
WSRC-TR-2000-00395

Page 19 of 40

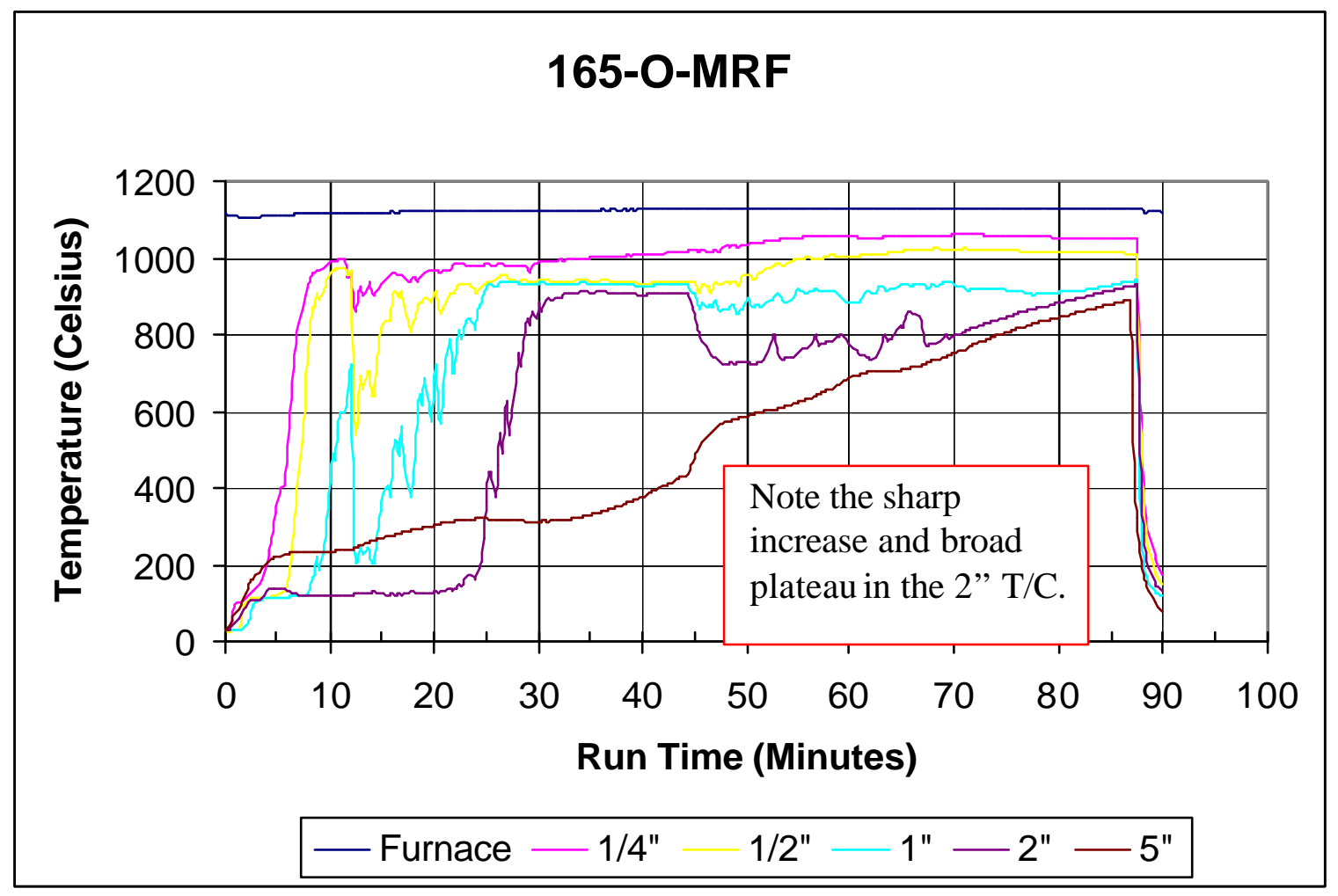

Figure 17. Temperature Profile: Frit 165 and Oxidizing Feed

\subsubsection{Feed Chemistry Comparison}

\subsubsection{Nitric Acid / Formic Acid Comparison}

The impact of varying the blend of nitric and formic acid additions during chemical cell processing was tested using three different types of feed in the melt rate furnace: oxidizing feed, blended feed, and reducing feed, as described in Appendix A. The oxidizing feed had the highest volume expansions, as shown in Figure 18, and slowest melt rates ( 1/2 the rate of reducing feed) with Frit 200. The blended feed produced a higher expansion than the reducing feed, but the blended feed melt rate was only slightly slower than the reducing feed, as shown in Figure 19. The results with blended feed and reducing feed indicate that melt rate can only be marginally improved by adjusting the nitric acid / formic acid ratio from the current flowsheet with Frit 200.

Both reducing and oxidizing feed were also run with Frit 131. The volume expansion with oxidizing feed caused a portion of the batch to be pushed out of the $1200 \mathrm{ml}$ beaker, while the volume expansion with reducing feed was well contained in the beaker. The reduced feed has a melt rate that was approximately $2 \mathrm{X}$ faster than oxidizing feed with Frit 131 as well as Frit 200, as shown in Figure 19 and Figure 20. 


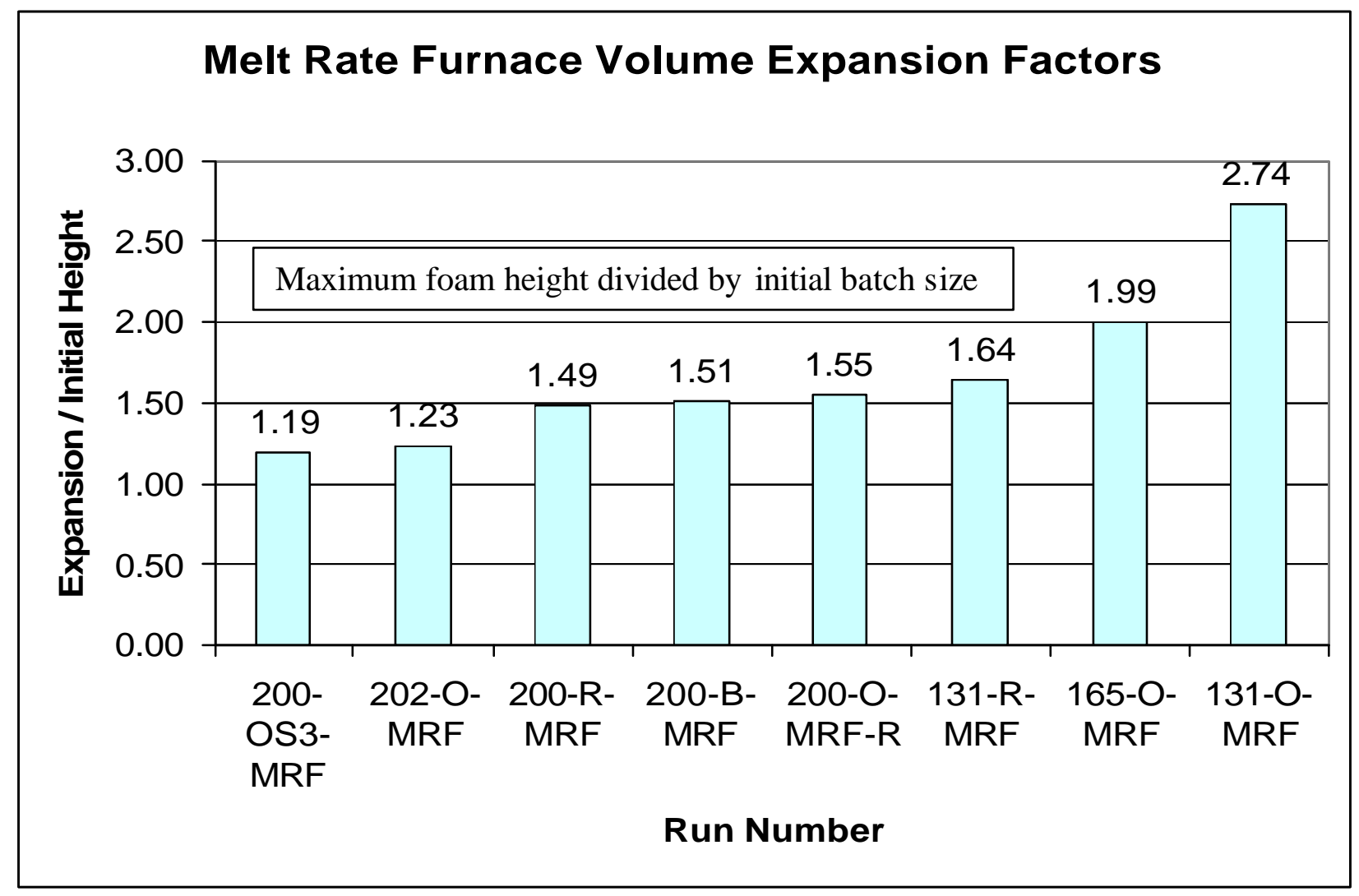

Figure 18. Volume Expansion Factors during Melt Rate Furnace Runs

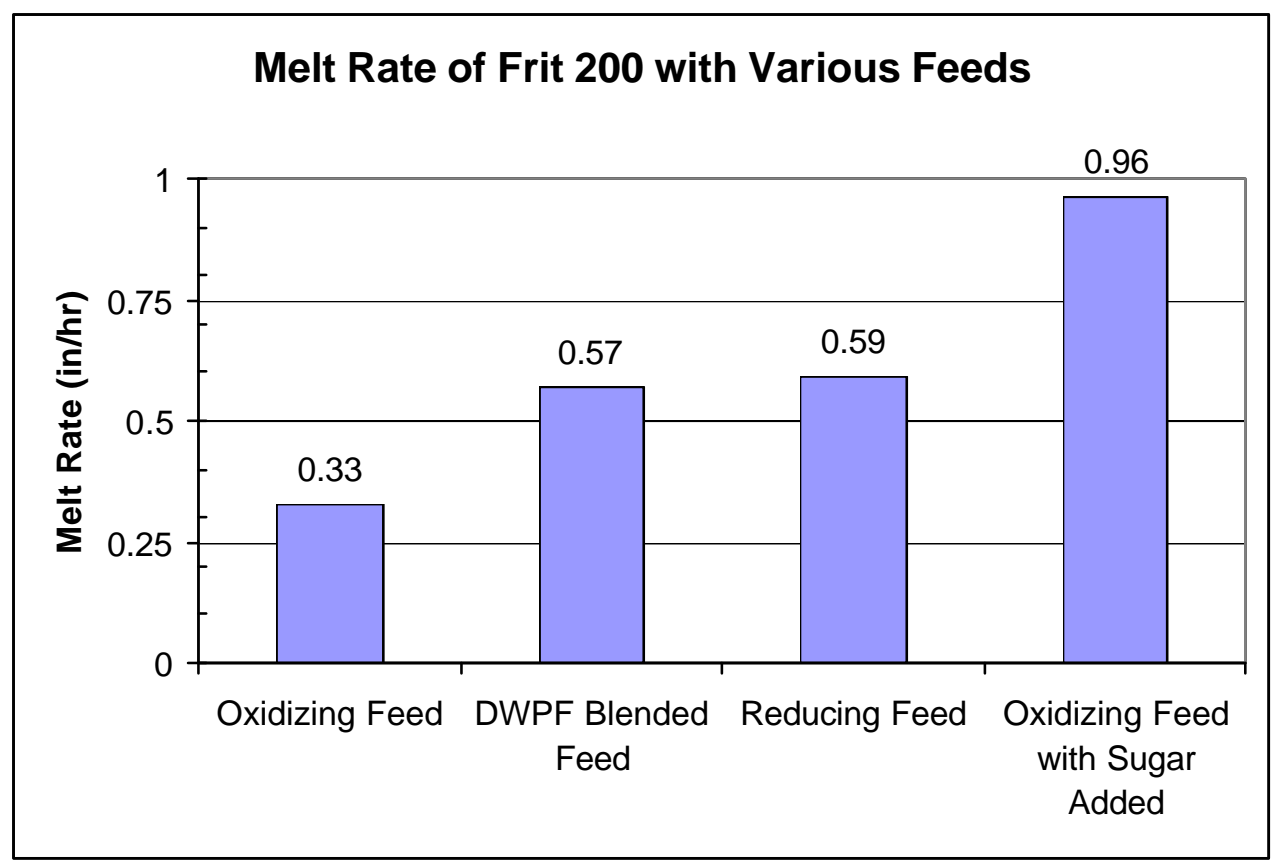

Figure 19. Impact of Feed Chemistry Changes on Melt Rate with Frit 200 
WSRC-TR-2000-00395

Page 21 of 40

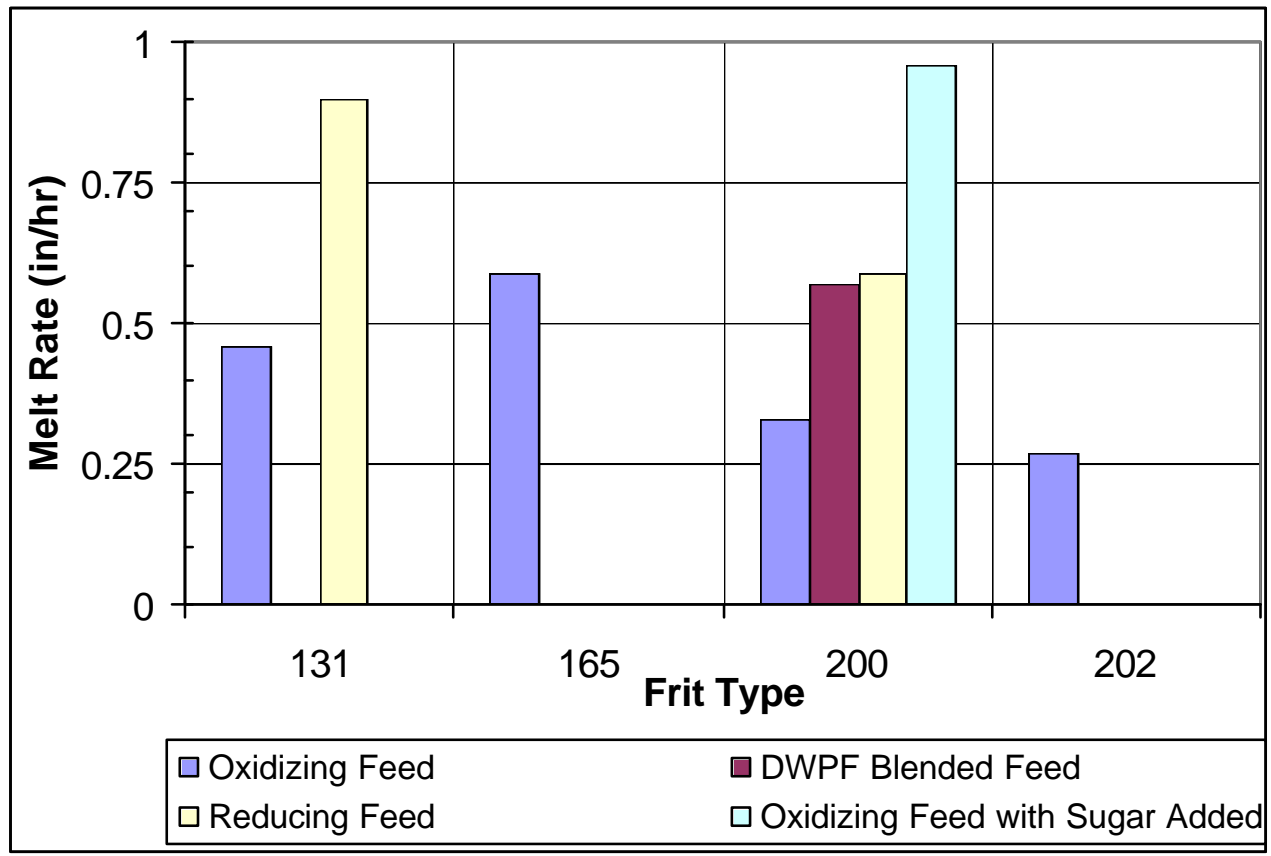

Figure 20. Melt Rates of Oxidizing, Blended, and Reducing Feeds.

\subsubsection{Alternative Reductant}

Sugar (sucrose) was tested as an alternative to formic acid. The amount of sugar required for oxidizing feed was determined by crucible testing to be 35 grams of sugar per 500 grams of glass based on reducing all nitrate in the feed to nitrogen gas, per the following equation:

$$
4 \mathrm{~N}^{+5}+5 \mathrm{C}^{0} \rightarrow 2 \mathrm{~N}_{2}^{0}+5 \mathrm{C}^{+4}
$$

The melt rate furnace run was made with oxidizing feed and 42 grams of sugar, approximately $20 \%$ more than required. Very little expansion was noted during the run and the melt rate was the highest of any run with frit 200, approximately three times faster than oxidizing feed without the sugar (as shown in Figure 19). The redox of the glass was measured to be 0.61, a close match with the redox measured during covered crucible tests, and well above the 0.33 limit for DWPF processing. Pictures of the sectioned crucibles are shown in Figure 21. 
WSRC-TR-2000-00395

Page 22 of 40

Figure 21. Sectioned Crucibles from Feed Chemistry Tests
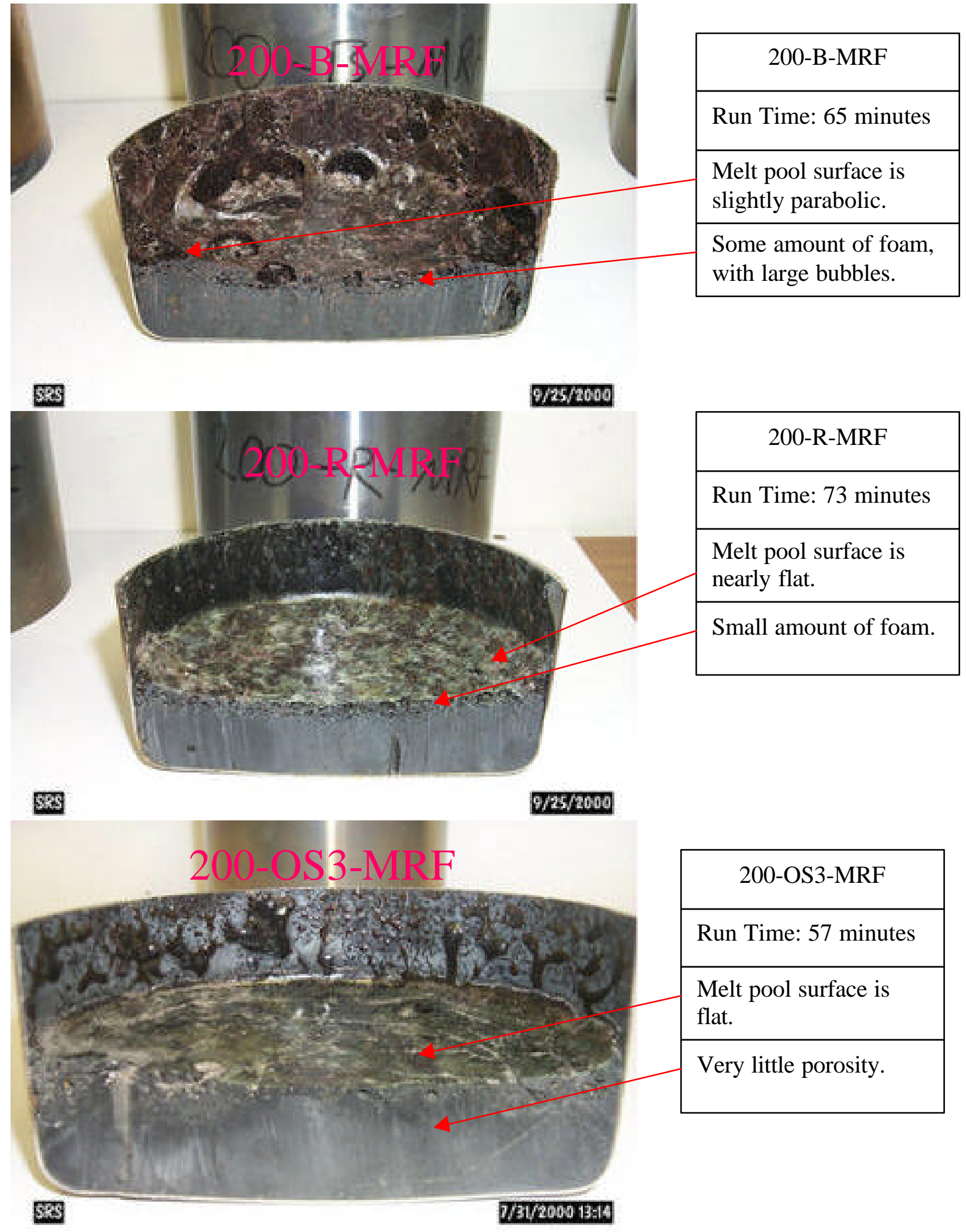
WSRC-TR-2000-00395

Page 23 of 40

\subsubsection{Slurry-Mixed Feed}

Initial melt rate furnace testing was conducted with feed that was prepared by mixing frit with dried SRAT product to expedite testing with different frit compositions. The SRAT product was not dried completely to avoid re-oxidation during drying and therefore, was slightly damp and could not be finely ground. The dried SRAT product was passed through a \#10 sieve prior to mixing with the frit. The large size of the dried SRAT product was not prototypical and affected the mixing of the frit with the feed.

Two runs were conducted with Frit 200 added to the SRAT product prior to drying, i.e. slurrymixed, to provide feed for the melt rate furnace that more closely matches the feed in the DWPF process. The runs were performed to determine if the melting behavior of the dried feed runs adequately simulated conditions in the DWPF to allow melt rate comparisons.

The mixed feed was dried at $93^{\circ} \mathrm{C}$ in an oven to the consistency of peanut butter prior to vitrification. The slurry-mixed feed contained approximately 150 grams more water after drying than the dry-mixed feed. The run time during both tests was 73 minutes, the same run time as the dry-mixed reduced feed run. The slurry-mixed batches had lower expansions versus those observed in the dry-blended runs conducted previously, as indicated by the temperature data shown in Appendix B (Tables B-15 and B-16). The sectioned beakers from the slurry-mixed runs with blended feed and reduced feed had similar appearance, with slightly less porosity in the reduced feed run. The sectioned beaker from the dry-mixed reduced feed run had slightly more porosity than the slurry-mixed run. Given that the slurry-mixed run had significantly more water, the melt rate in the slurry-mixed run was slightly faster than the dry-mixed run, but the relative result between the blended feed and reduced feed remained the same with the slurrymixed tests as with the dry-mixed feed.

The appearance of the feed prior to vitrification in the melt rate furnace was also dramatically different between the slurry-mixed and dry-mixed feed The slurry of frit and SRAT product was similar in color to the SRAT product prior to frit addition, while the dry blended batch retained the color of the frit as the predominate color. Since the frit particles are much larger than the sludge particles in the SRAT product slurry, the sludge coats each frit particle during mixing, in contrast to dried feed where the large SRAT product clumps becomes coated with the smaller frit particles.

The change in melting behavior likely results from the coating of sludge on the frit during slurry mixed runs preventing a continuous phase of lightly loaded (and highly viscous) glass from forming during the melting process. During dry mixed runs, the frit can form a continuous liquid phase prior to reacting with the feed. The frit phase would be highly viscous since the flux from the feed is not present. Therefore, the frit phase would trap gas very efficiently and cause higher volume expansions.

\subsubsection{Manganese Concentration}

The effect of manganese concentration in the melter feed on the volume expansion and melt rate was tested by running low and high Mn concentration feed in the melt rate furnace. The high 
WSRC-TR-2000-00395

Page 24 of 40

manganese run utilized Tank 40 SRAT product that was adjusted to $6 \%$ manganese while the low manganese run utilized Tank 40 SRAT product that was $1.2 \%$ manganese. These runs utilized batches prepared by mixing Frit 200 with the SRAT product as a slurry (targeting a 25 wt\% loading), then drying the batch at $93^{\circ} \mathrm{C}$ to the consistency of peanut butter prior to vitrification.

The volume expansion was more severe and the melt rate was slower during the high manganese run. The cold cap burned off before the manganese had completed offgassing, therefore the complete impact of the higher manganese concentration could not be estimated from the runs.

\subsubsection{Frit Comparison}

Four different frits were tested with oxidizing feed in the melt rate furnace: Frit 131, Frit 165, Frit 200, and Frit 202. The volume expansions and melting rate varied considerably between the different frits. A higher volume expansion did not directly lead to slower melting, as the two frits with the highest expansions also had the fastest melt rates, indicating that the frits with larger volume expansions produced foam that was less stable than the foam produced by the runs with smaller expansions.

The volume expansion was inversely related to the melting point of the frit: volume expansions decreased as melting point increased. The volume expansion during runs with Frit 131 exceeded the volume of the $1200 \mathrm{ml}$ beaker, while the expansion with Frit 202 only half filled the beaker. The differences in volume expansions are shown above in Figure 18.

Melt rate varied considerably from the fastest to the slowest frit with Frit 165 melting approximately twice as fast as Frit 202 and Frit 200, as shown in Figure 22. The melt rate with Frit 131 was not as fast as with Frit 165, probably due to the extreme volume expansion with Frit 131. As shown in Figure 23, Frits 131 and 165 produced glass with very little porosity after run times of 100 and 88 minutes, respectively. The glass from the runs with Frits 200 and 202 still contained a considerable amount of porosity after runs of 111 and 123 minutes.

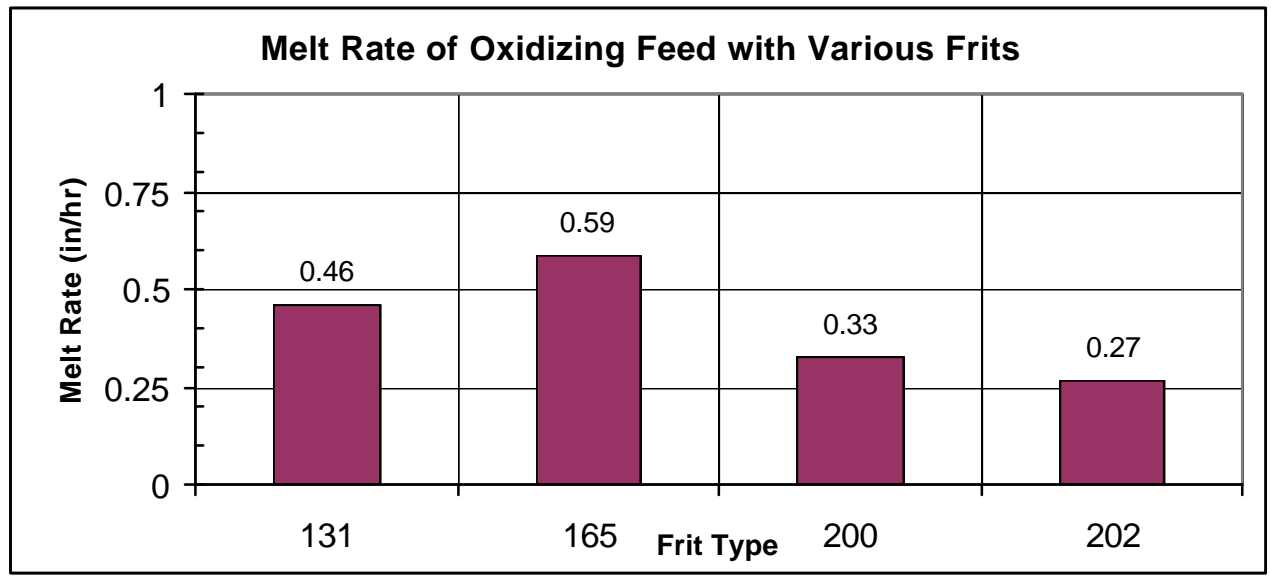

Figure 22. Melt Rates of Oxidizing SRAT Product with Various Frits 
WSRC-TR-2000-00395

Page 25 of 40

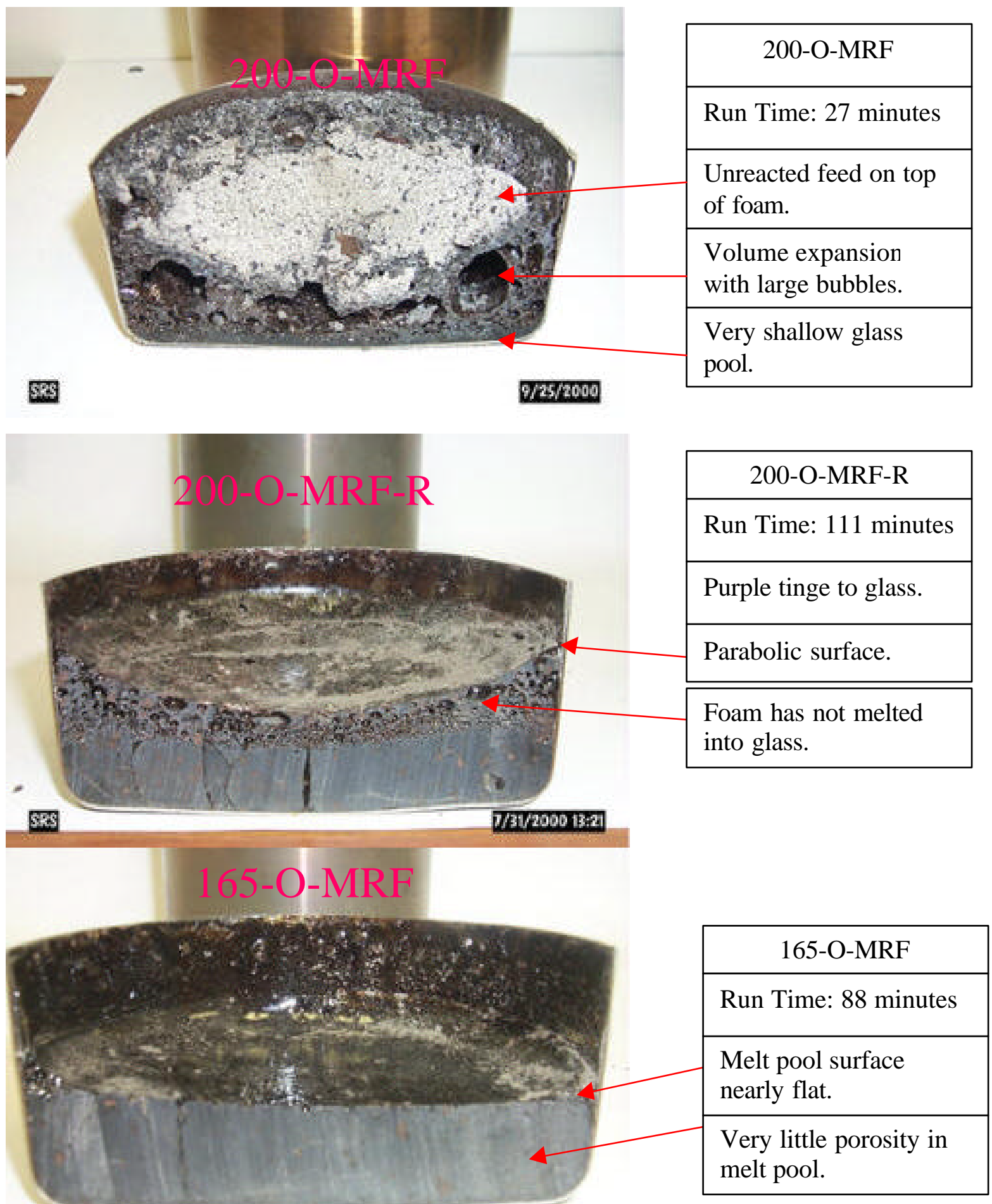

Figure 23. Sectioned Crucibles from Frit Composition Tests 
WSRC-TR-2000-00395

Page 26 of 40

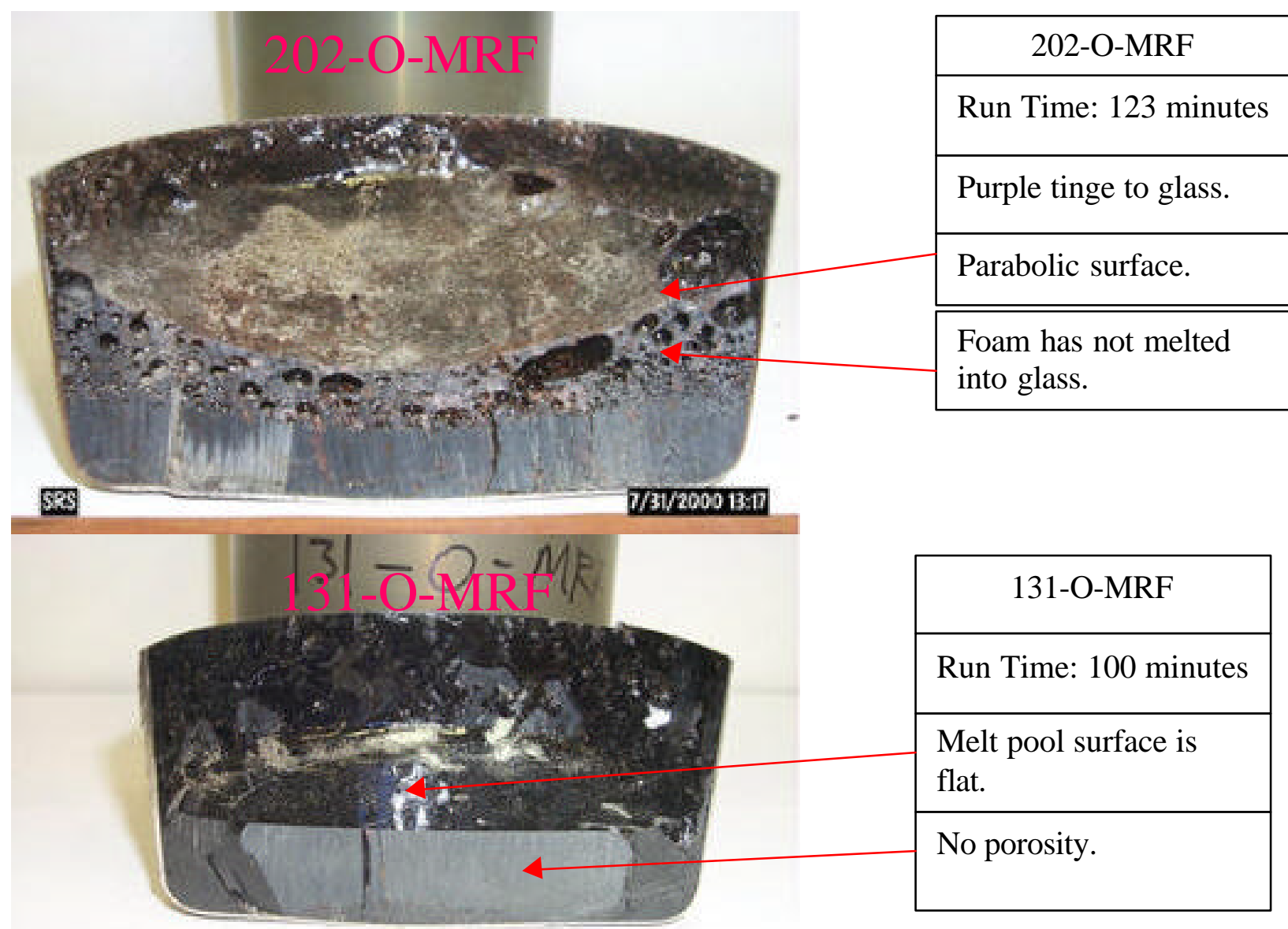

5RS

$9 / 25 / 2000$

Figure 23. Sectioned Crucibles from Frit Composition Tests, Continued

\subsection{CONCLUSIONS}

The melt rate testing in FY00 demonstrated that melt rate can be improved by adding a different frit or producing a much more reducing glass by the addition of sugar as a reductant. The frit that melted the fastest in the melt rate testing was Frit 165. A paper study was performed using the Product Composition Control System (PCCS) to determine the impact on predicted glass viscosity, liquidus, durability, and operating window if the frit was changed from Frit 200 to Frit 165. PCCS indicated that the window was very similar for both frits. In addition, the predicted viscosity of the frit 165 glass was 46 poise versus 84 poise for the Frit 200 glass. As a result, a change from Frit 200 to Frit 165 is expected to increase the melt rate in DWPF without decreasing waste loading. The data is summarized in Appendix C.

A change to a formic acid only flowsheet would lead to a very small increase in melt rate. The addition of sugar as an additional reductant would lead to a large melt rate increase but would 
WSRC-TR-2000-00395

Page 27 of 40

likely create a glass that is too reducing $(>0.33 \mathrm{Fe}+2 / \Sigma \mathrm{Fe})$ for the DWPF melter. Additional work (e.g. melter offgas flammability, melter feed rheology, and redox correlation) needs to be performed in this area.

The list below summarizes most of the important results from this testing:

- The melt rate furnace is capable of measuring relative melt rate and volume expansion height.

- The melt rate for a given frit composition can be increased dramatically by reducing the size of the volume expansion through use of an effective reductant.

- Sugar was more effective than formic acid in reducing volume expansions and improving melt rate.

- Frit composition changes can be used to improve melt rate, with Frit 165 melting the fastest of the four frits tested with oxidizing feed.

- Changing the ratio of nitric acid to formic acid only slightly increases melt rate.

- Batches with frit and SRAT product blended as a slurry exhibited different melting behavior than batches with frit and SRAT product blended after drying, but the relative results between blended feed and reducing feed were not affected.

\subsection{FUTURE TESTS}

The FY00 testing was based on combining dried SRAT product with frit to produce a dry melter feed. FY01 testing will combine a SRAT product slurry and frit to produce a melter feed that will be dried prior to melt rate testing. There are no plans to use a dried SRAT product in FY01 testing. However, the best test of the melt rate would be to feed a slurry to a molten glass pool. The development of a slurry fed melt rate furnace or the measurement of the melt rate in a melter would give increased confidence in the results of the FY01 melt rate testing. In addition, sufficient duplication of experiments is necessary to determine the repeatability of the testing. Based on what was learned in the FY00 melt rate testing, the following is a list of tasks to be performed in FY01:

1. Evaluate changes in frit composition, glass former type (e.g. batch chemicals), and melter feed redox to improve the melt rate of Macrobatch 3.

- Focus initially on frit composition changes.

- Evaluate the use of Frit 165 and new frit compositions to improve melt rate of Macrobatch 3.

- Melter feed acceptability should be evaluated with appropriate models to ensure glass durability, liquidus, and viscosity are acceptable.

- Continue testing to understand the mechanism causing foam formation.

- Blend frit and SRAT product as a slurry.

- Utilize the tools developed for Macrobatch 2.

- Develop the necessary tools to determine melt rate during slurry feeding.

- Evaluate glass durability, liquidus, viscosity, and predicted redox to determine the feasibility of proposed changes.

- Develop redox prediction models for any proposed changes to the reductant type. 
WSRC-TR-2000-00395

Page 28 of 40

- Evaluate flammability calculations for any proposed chemical processing changes.

- Perform enough duplicate runs to estimate the repeatability of the melt rate tests.

- Demonstrate the feasibility of the new processing changes in the 786-A minimelter.

- Evaluate impact on melt rate of increased washing of Sludge Batch 2.

2. The following analyses of radioactive DWPF samples are recommended to validate the results of the small-scale experiments. ITS will investigate the cost and tasks necessary to perform these measurements in the Shielded Cells. The SRAT and SME analysis will be requested from DWPF. DWPF samples should be analyzed before and after the processing changes to determine the if the changes were effective.

- Measurement of the redox of the DWPF Glass (shielded cells or DWPF analytical lab) during Macrobatch 2 and Macrobatch 3.

- Measurement of the total and soluble cations (Mn is most important) in DWPF Sludge Receipt and Adjustment Tank product, Slurry Mix Evaporator product and Melter Feed Tank.

\subsection{REFERENCES}

1. D. P. Lambert, Experimental Plan for Melt Rate Crucible Studies, SRT-PTD-200000014, Revision 1, June 8, 2000

2. Task Technical and QA Plan, WSRC-RP-2000-00080, January 27, 2000.

3. Technical Task Request, HLW/DWPF/TTR-00-0006, November 22, 1999.

4. K. G. Brown, C. M. Jantzen, and J. B. Pickett, The Effects of Formate and Nitrate on Reduction/Oxidization (Redox) Process Control for the Defense Waste Processing Facility (DWPF) (U), WSRC-RP-97-34, February 5, 1997.

5. Laboratory Notebook, WSRC-NB-99-00170

6. Laboratory Notebook, WSRC-NB-2000-00106 
WSRC-TR-2000-00395

Page 29 of 40

\subsection{APPENDIX A: SRAT PRODUCT PREPARATION AND FRIT COMPOSITIONS}

The melter feeds for the melt rate experiments were produced by combining a "simulated DWPF SRAT $^{1}$ product" with frit. No DWPF SME cycles ${ }^{2}$ were simulated in this testing. The "simulated DWPF SRAT product" was produced at TNX in shortened SRAT cycles designed to fit into a 9-hour workday. The simulants were made with a Tank 42 (DWPF macrobatch 2) sludge simulant. All of the simulated sludge used in this testing was prepared from the same sludge drum (Drum G). No noble metals or mercury were added to the sludge. The work is summarized in a lab notebook (WSRC-NB-99-00170).

To simulate the range of oxidizing and reducing SRAT products, only very oxidizing (virtually all nitric acid) and very reducing (only formic acid) SRAT products were produced. The acid strategy used in these experiments is that used by DWPF, $150 \%$ acid stoichiometry, sludge only process. Combining these two extremes will produce any intermediate SRAT product. A total of twelve 3-liter batches of oxidizing feed and twelve 3-liter batches of reducing feed were produced to support the FY00 testing. The SRAT products were oven-dried at approximately $90^{\circ} \mathrm{C}$, combined together, sampled and analyzed as summarized in Table A-1.

To prepare melter feeds for the crucible and melt rate furnace tests, the dried SRAT product was combined with frit to prepare a glass that was $25 \%$ SRAT oxides and $75 \%$ frit. The SRAT products were dried because the water in a slurry might flash off and cause loss of solids. As a result, all planned testing was with dried SRAT product and frit.

One of the concerns in the early testing was the highly oxidized appearance of the glasses that were being produced. Denny Bickford and Carol Jantzen were concerned that the rose color of most of the glasses was a result of an overly oxidizing melter feed. Experience has shown that reduction of $>50 \%$ of the Mn during SRAT and SME processing is necessary to prevent foaming problems in melters associated with the reduction of the $\mathrm{Mn}$ in the melter. The reduction of any metal oxide in the melter leads to the release of oxygen that is easily trapped by the glass or a viscous cold cap.

To determine whether the SRAT product was overly oxidized compared to the DWPF SRAT product, the SRAT product was analyzed for total and soluble $\mathrm{Mn}$. $\mathrm{Mn}^{+4}$ is insoluble in our SRAT product and $\mathrm{Mn}^{+2}$ is soluble at typical temperatures in our SRAT product. The ratio of soluble to total manganese is used to calculate the percentage of $\mathrm{Mn}^{+2}$ in the SRAT product. Testing demonstrated that $30 \%$ to $36 \%$ of the Mn was soluble in our SRAT product preparation. This compares with the 33\% measured by DWPF based on a sludge batch 160 sample. Frit compositions are shown in Table A-2.

\footnotetext{
${ }^{1}$ Sludge Receipt and Adjustment Tank (SRAT) processing includes the addition of nitric and formic acid at $93^{\circ} \mathrm{C}$, concentration of the SRAT contents to 6000 gallons, twelve hours of total boiling followed by a cooldown of the SRAT contents to $50^{\circ} \mathrm{C}$. A typical SRAT cycle takes a minimum of 18 hours.

${ }^{2}$ Slurry Mix Evaporator (SME) processing includes the addition of a frit/water slurry along with the concentration of the SME contents to $\sim 6000$ gallons followed by a cooldown of the SME contents to $50^{\circ} \mathrm{C}$. A typical SRAT cycle takes a minimum of 24-72 hours.
} 
WSRC-TR-2000-00395

Table A-1. Compositions of Sludge Used During Melt Rate Tests

\begin{tabular}{|c|c|c|c|c|}
\hline Analyses & \multicolumn{2}{|c|}{ Reducing Sludge } & \multicolumn{2}{|c|}{ Oxidizing Sludge } \\
\hline \begin{tabular}{||l|} 
total solids \\
calcined wt \%
\end{tabular} & \multicolumn{2}{|c|}{$\begin{array}{l}77.75 \% \\
54.65 \%\end{array}$} & \multicolumn{2}{|c|}{$\begin{array}{l}88.20 \% \\
57.70 \%\end{array}$} \\
\hline Cations & elemental & oxide & elemental & oxide \\
\hline Aluminum & $10.725 \mathrm{wt} \%$ & 20.265 wt\% & 10.550 wt\% & $19.934 \mathrm{wt} \%$ \\
\hline Boron & $0.000 \mathrm{wt} \%$ & $0.000 w t \%$ & $0.000 \mathrm{wt} \%$ & $0.000 w t \%$ \\
\hline Calcium & $3.525 \mathrm{wt} \%$ & $4.932 \mathrm{wt} \%$ & $3.688 \mathrm{wt} \%$ & $5.160 \mathrm{wt} \%$ \\
\hline Chromium & 0.236 wt $\%$ & $0.344 w t \%$ & $0.223 \mathrm{wt} \%$ & $0.326 \mathrm{wt} \%$ \\
\hline Copper & 0.033 wt $\%$ & $0.037 w t \%$ & $0.034 \mathrm{wt} \%$ & $0.038 w t \%$ \\
\hline Iron & $28.200 \mathrm{wt} \%$ & 40.318 wt $\%$ & $28.025 \mathrm{wt} \%$ & $40.067 \mathrm{wt} \%$ \\
\hline Potassium & $0.188 w t \%$ & $0.226 \mathrm{wt} \%$ & $0.180 \mathrm{wt} \%$ & $0.216 \mathrm{wt} \%$ \\
\hline Lithium & 0.000 wt $\%$ & $0.000 \mathrm{wt} \%$ & $0.000 \mathrm{wt} \%$ & $0.000 w t \%$ \\
\hline Magnesium & $1.705 \mathrm{wt} \%$ & $2.827 \mathrm{wt} \%$ & $1.693 \mathrm{wt} \%$ & 2.806 wt\% \\
\hline Manganese & $4.145 \mathrm{wt} \%$ & $5.352 \mathrm{wt} \%$ & $4.053 \mathrm{wt} \%$ & $5.233 \mathrm{wt} \%$ \\
\hline Sodium & $10.168 \mathrm{wt} \%$ & $13.706 \mathrm{wt} \%$ & $8.248 w t \%$ & $11.118 \mathrm{wt} \%$ \\
\hline Nickel & 0.360 wt $\%$ & 0.458 wt $\%$ & 0.341 wt $\%$ & 0.434 wt\% \\
\hline Silicon & $1.161 \mathrm{wt} \%$ & $2.484 \mathrm{wt} \%$ & $1.109 \mathrm{wt} \%$ & $2.372 \mathrm{wt} \%$ \\
\hline Titanium & 0.058 wt $\%$ & $0.097 w t \%$ & $0.055 w t \%$ & $0.092 \mathrm{wt} \%$ \\
\hline Zirconium & $0.046 \mathrm{wt} \%$ & $0.054 \mathrm{wt} \%$ & $0.044 \mathrm{wt} \%$ & $0.052 \mathrm{wt} \%$ \\
\hline \multicolumn{5}{|l|}{ Anions } \\
\hline Formate & \multicolumn{2}{|c|}{$2,500 \mathrm{mg} / \mathrm{kg}$} & \multicolumn{2}{|c|}{$161,500 \mathrm{mg} / \mathrm{kg}$} \\
\hline Jitr & \multicolumn{2}{|l|}{253} & \multicolumn{2}{|c|}{$25,600 \mathrm{mg} / \mathrm{kg}$} \\
\hline
\end{tabular}

Table A-2. Frit Compositions

\begin{tabular}{|l|c|c|c|c|}
\hline Component & 131 & 165 & 200 & 202 \\
\hline $\mathrm{SiO}_{2}$ & 57.9 & 68.0 & 70.0 & 77.0 \\
\hline $\mathrm{Na}_{2} \mathrm{O}$ & 17.7 & 13.0 & 11.0 & 6.0 \\
\hline $\mathrm{Li}_{2} \mathrm{O}$ & 5.7 & 7.0 & 5.0 & 7.0 \\
\hline $\mathrm{B}_{2} \mathrm{O}_{3}$ & 14.7 & 10.0 & 12.0 & 8.0 \\
\hline $\mathrm{MgO}$ & 2.0 & 1.0 & 2.0 & 2.0 \\
\hline $\mathrm{TiO}_{2}$ & 1.0 & - & - & - \\
\hline $\mathrm{La}_{2} \mathrm{O}_{3}$ & 0.5 & - & - & - \\
\hline $\mathrm{ZrO}_{2}$ & 0.5 & 1.0 & - & - \\
\hline
\end{tabular}


WSRC-TR-2000-00395

Page 31 of 40

\subsection{APPENDIX B: MELT RATE FURNACE TEMPERATURE CHARTS}

Figure B-1. Initial Testing Run with Frit 200 Only

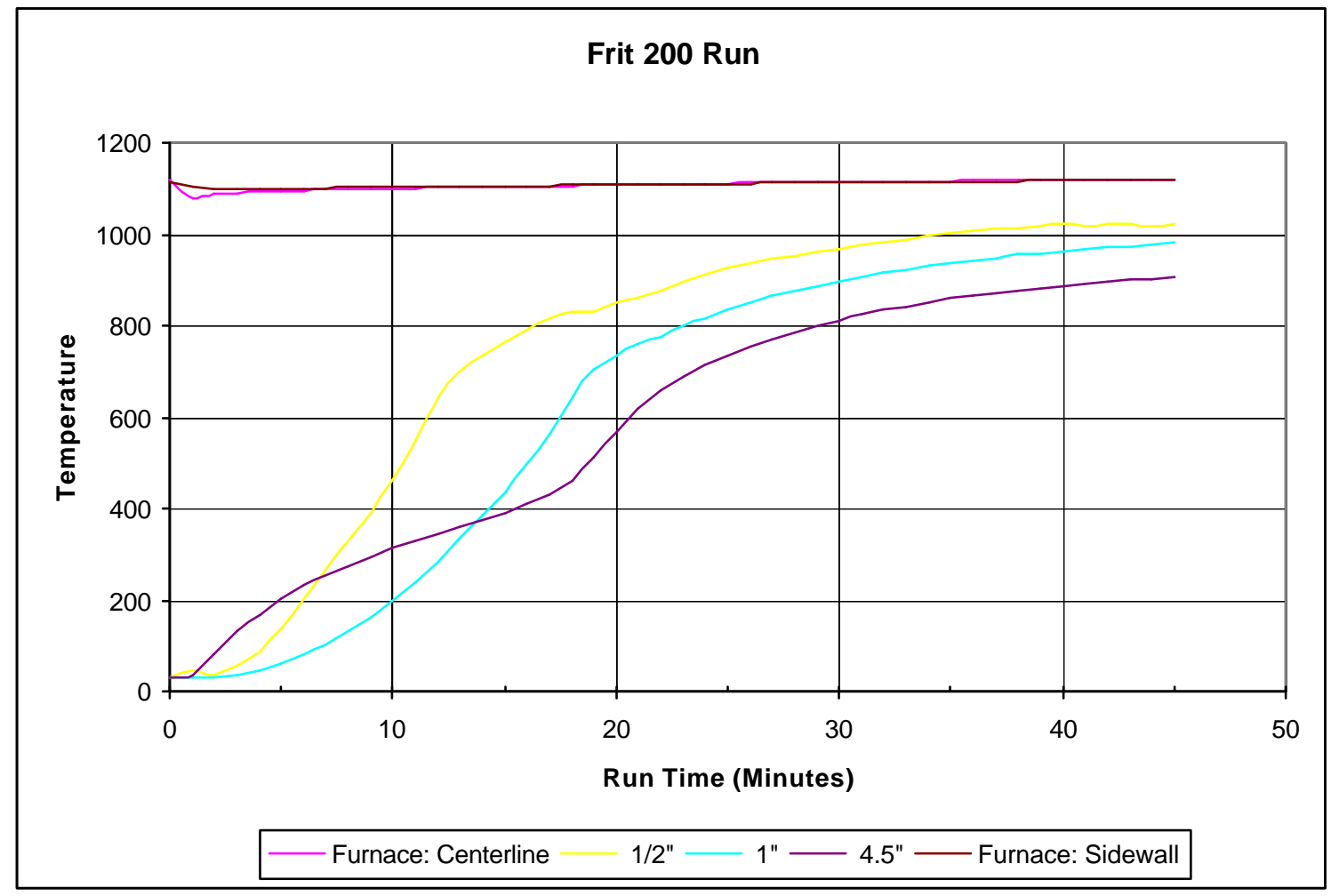

Figure B-2. Initial Testing Run with Frit 131 Only

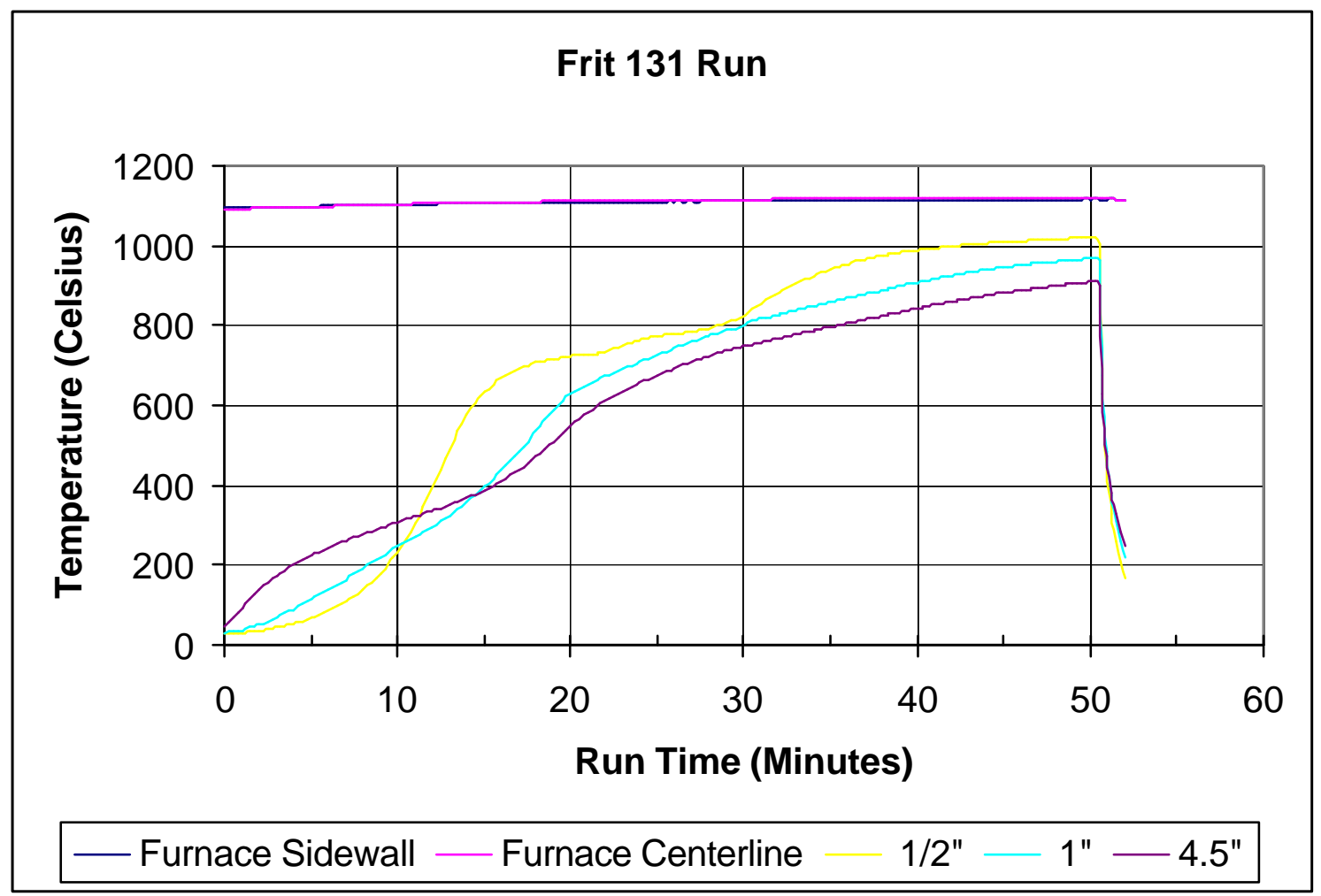


Figure B-3. 200-O-MRF: Oxidizing Feed and Frit 200

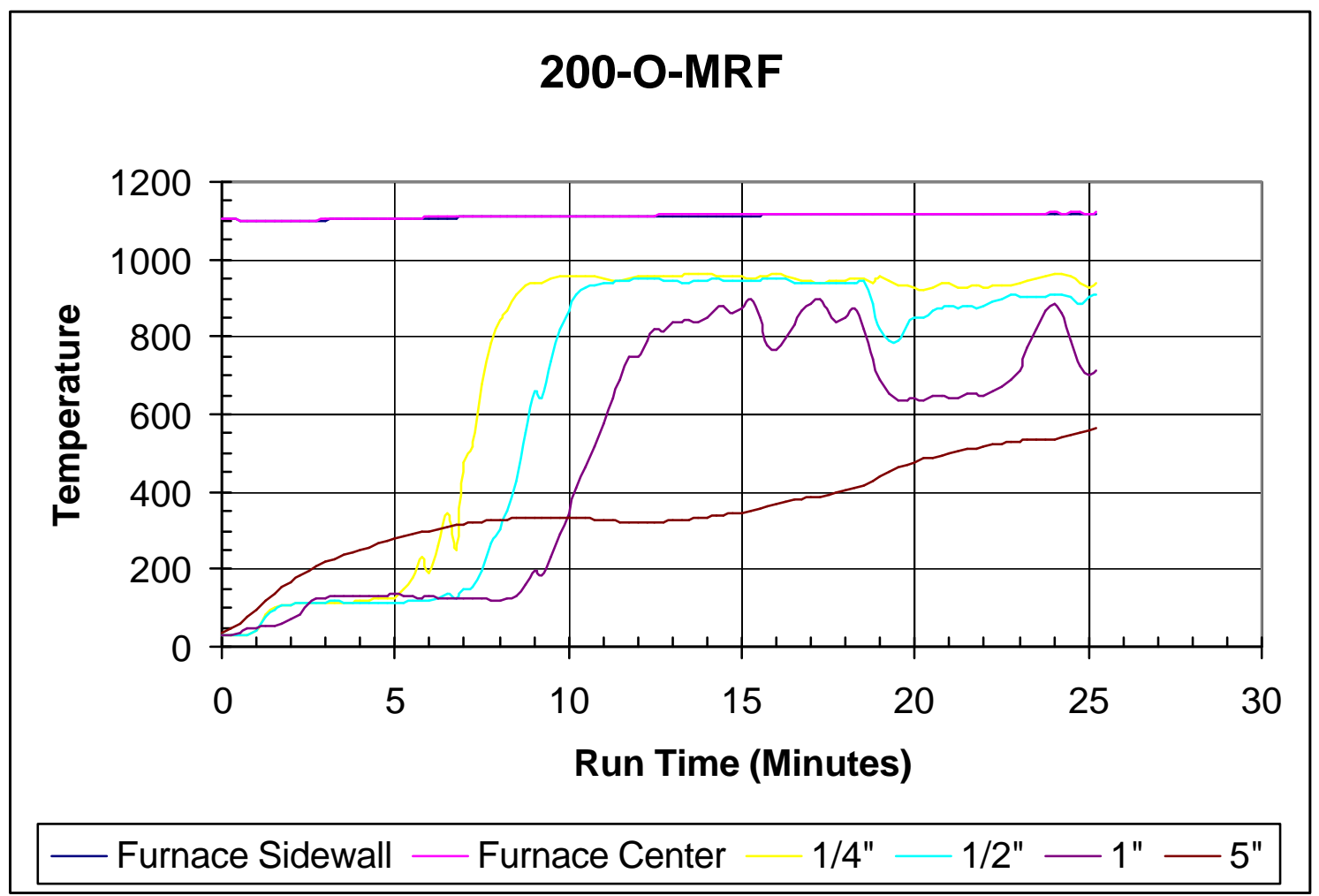

Figure B-4. 200-O-MRF-R: Oxidizing Feed and Frit 200 with Longer Run Time

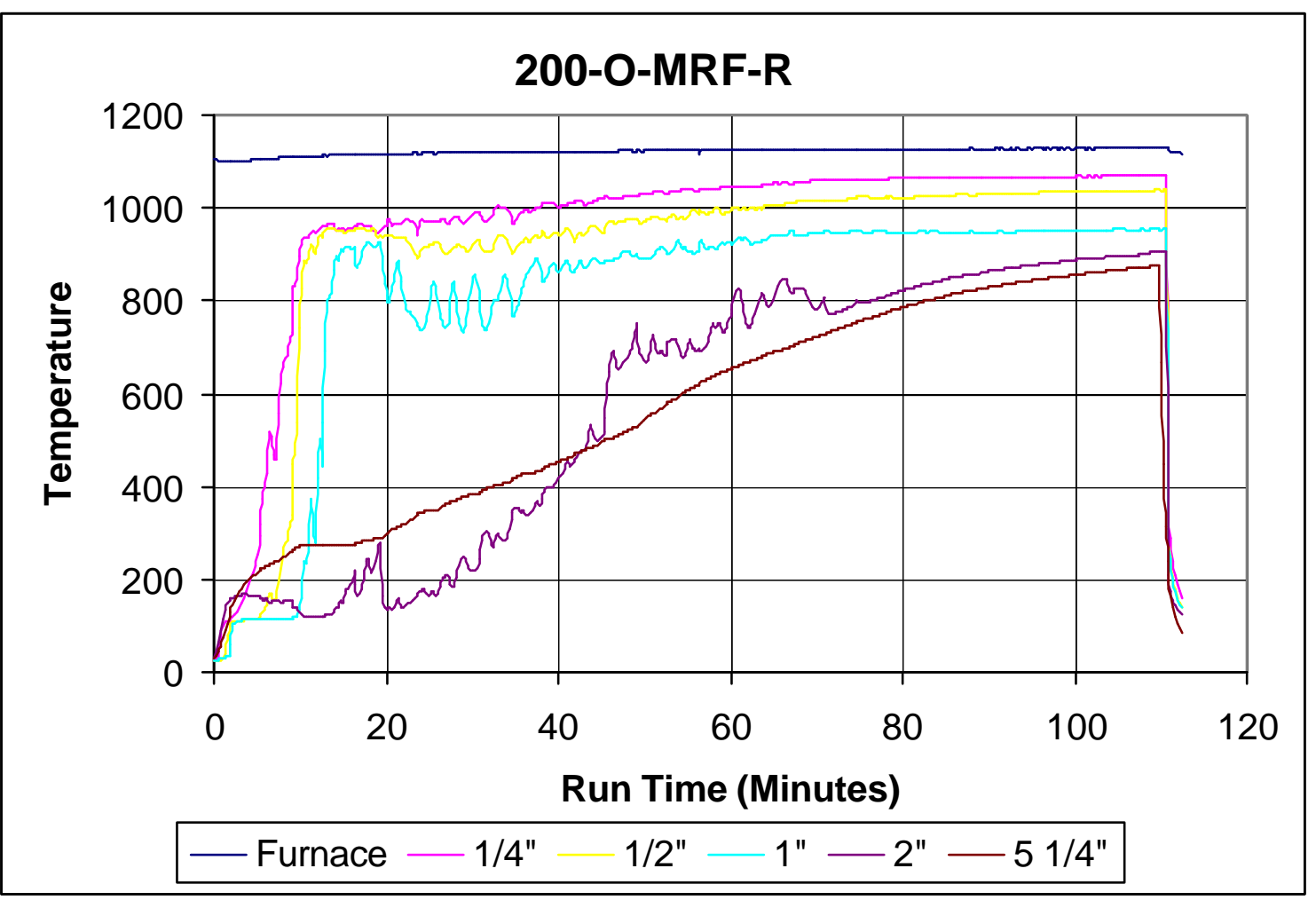


Figure B-5. 200-OS-MRF: Oxidizing Feed, Sugar, and Frit 200

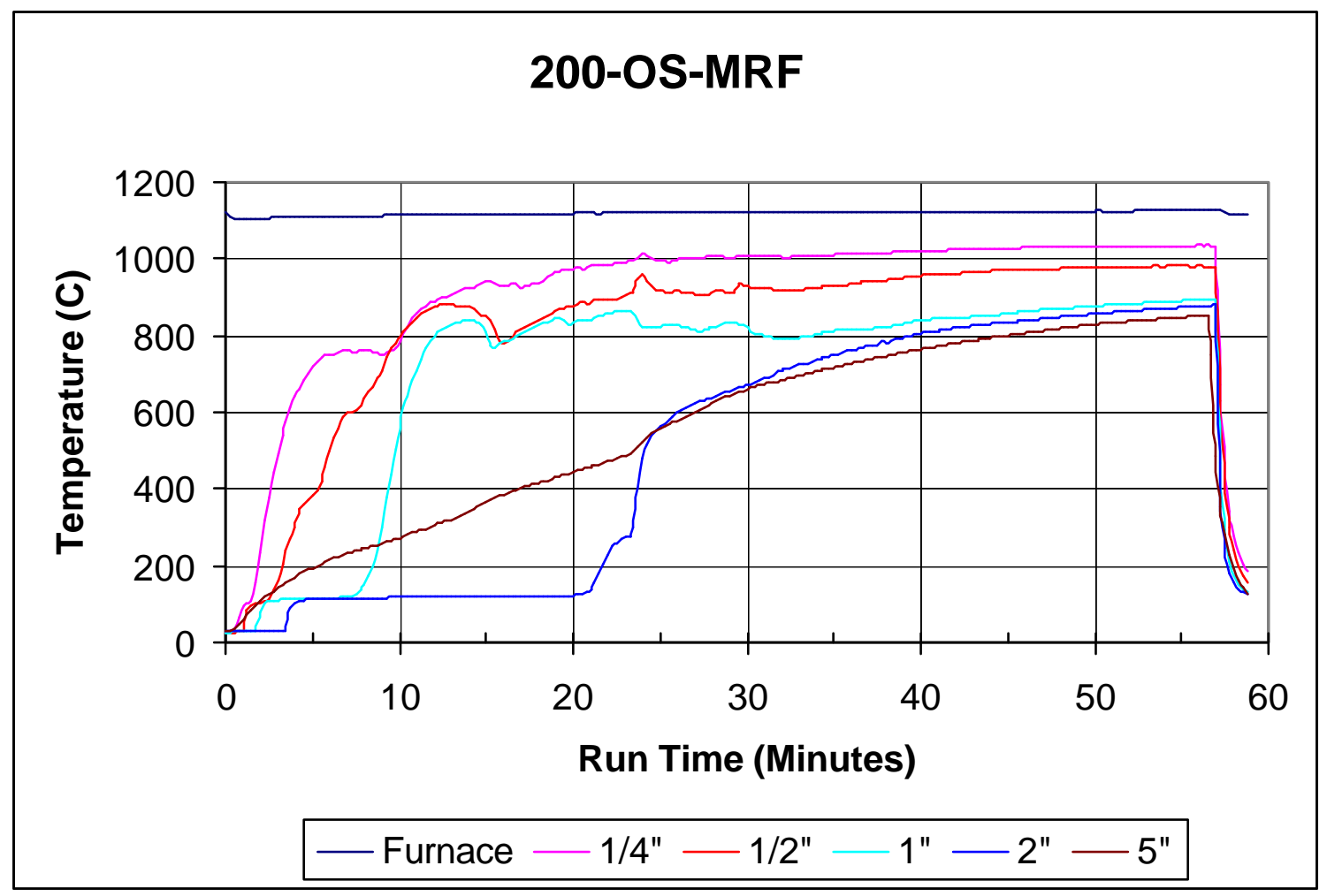

Figure B-6. 165-O-MRF: Oxidizing Feed and Frit 165

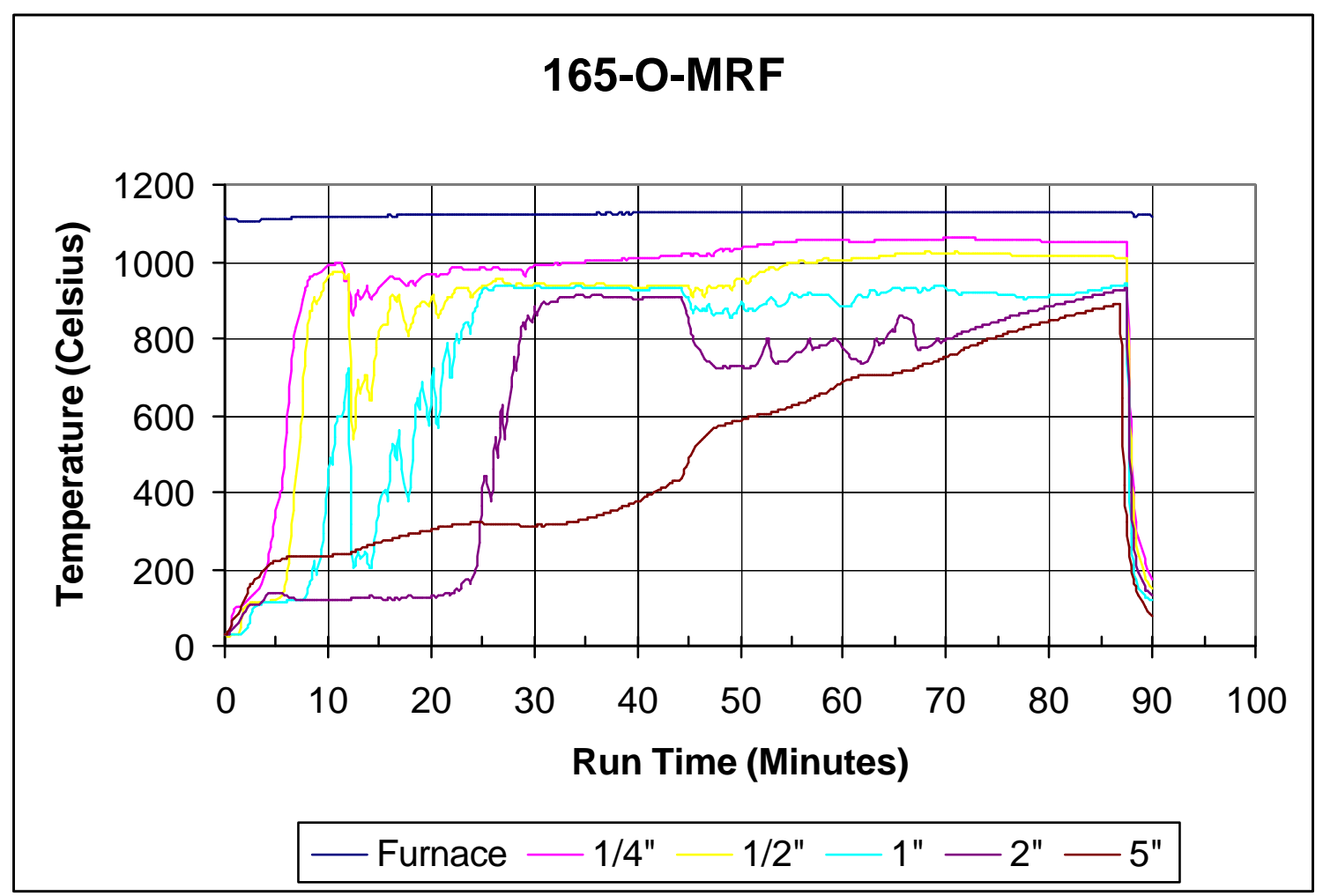


Figure B-7. 202-O-MRF: Oxidizing Feed and Frit 202

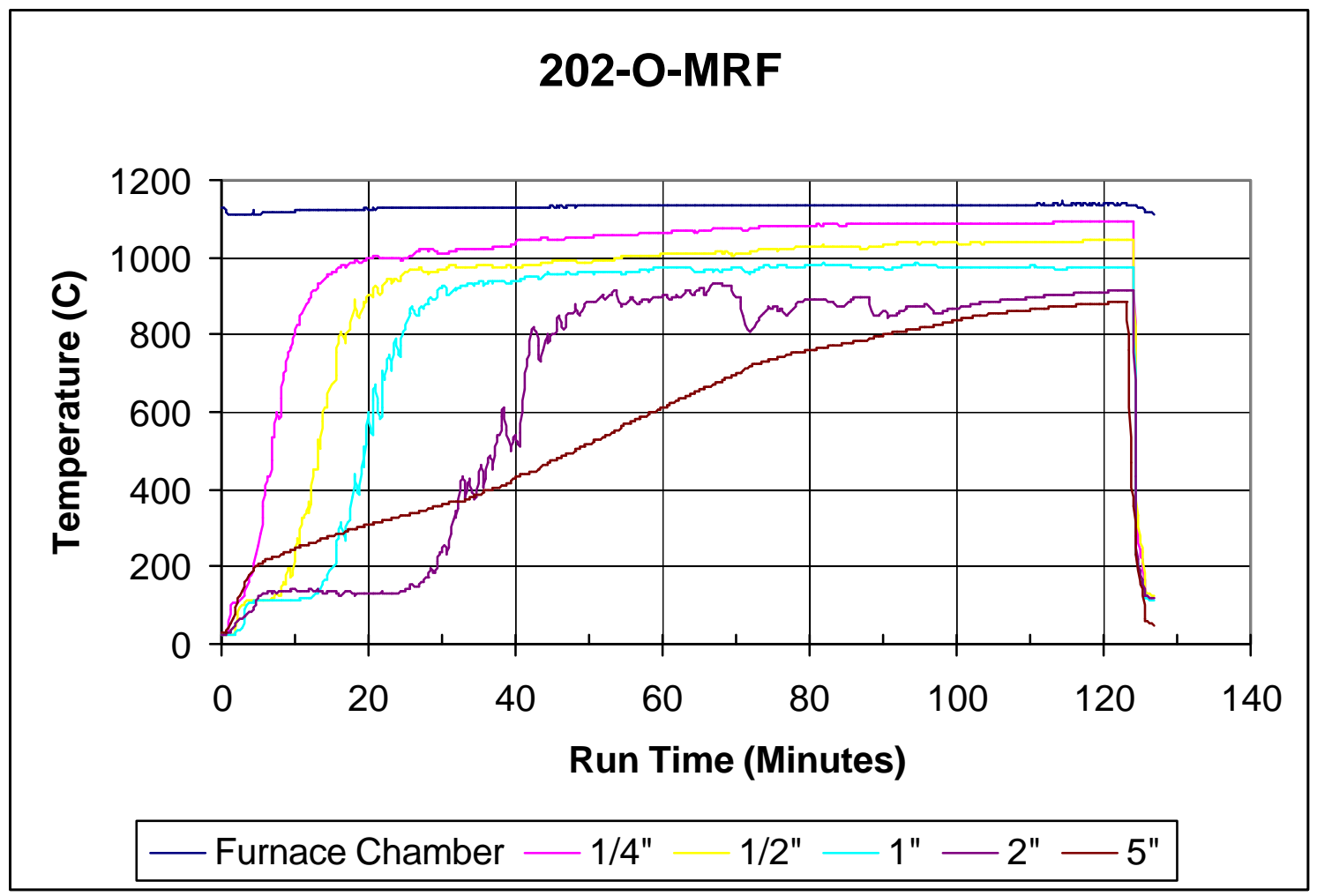

Figure B-8. 131-O-MRF: Oxidizing Feed and Frit 131

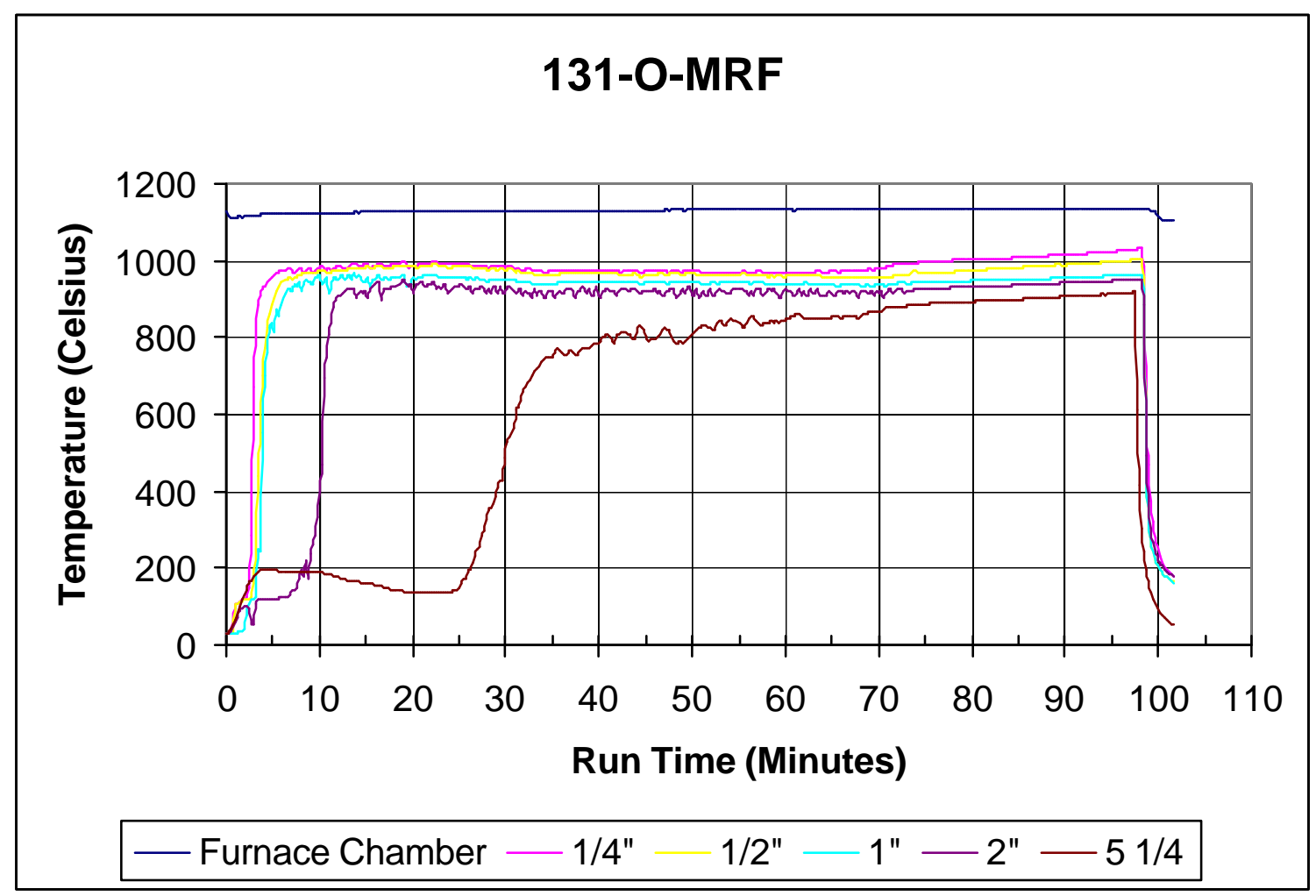


Figure B-9. 200-R-MRF: Reducing Feed and Frit 200

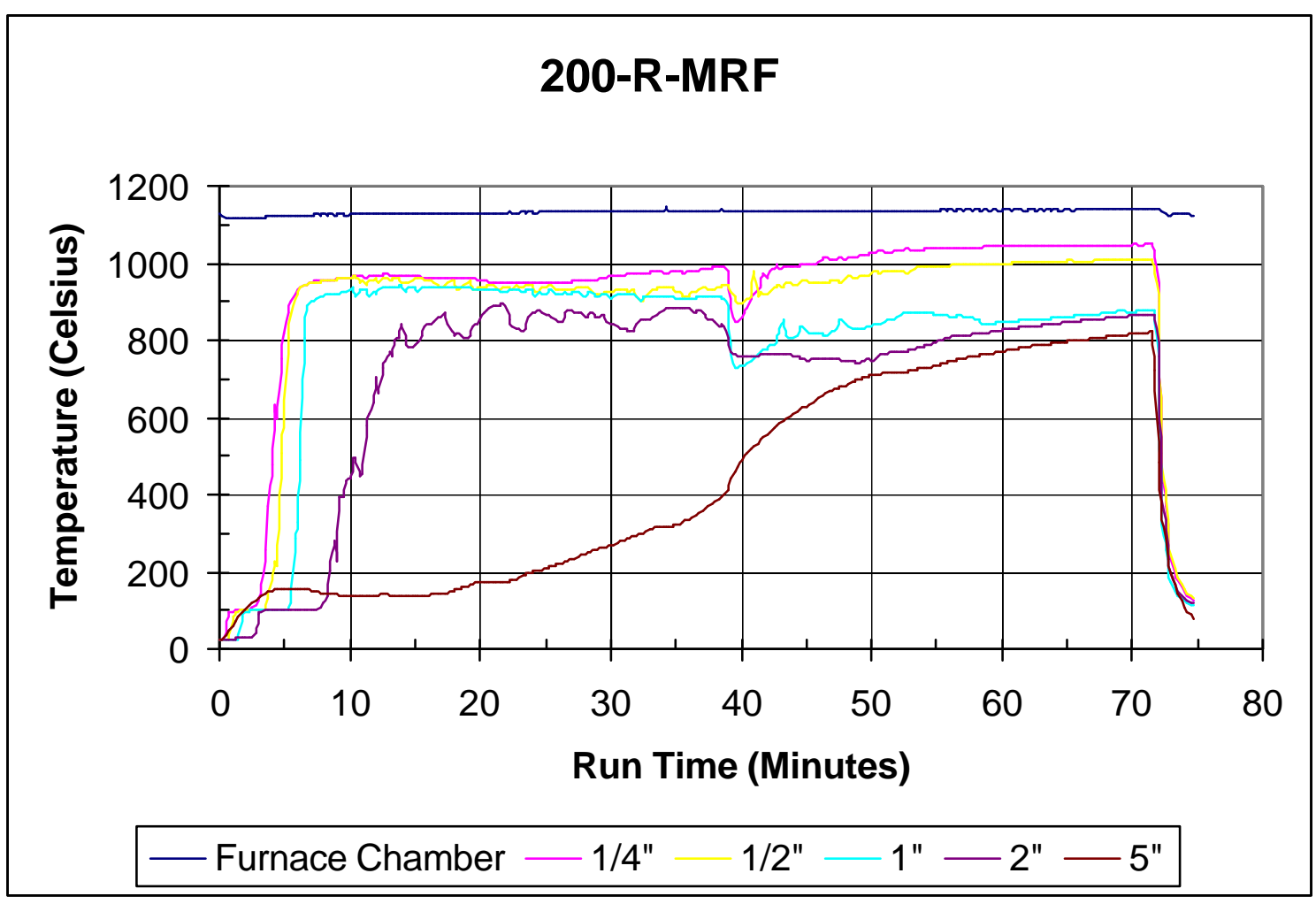

Figure B-10. 200-B-MRF: Blended Feed and Frit 200

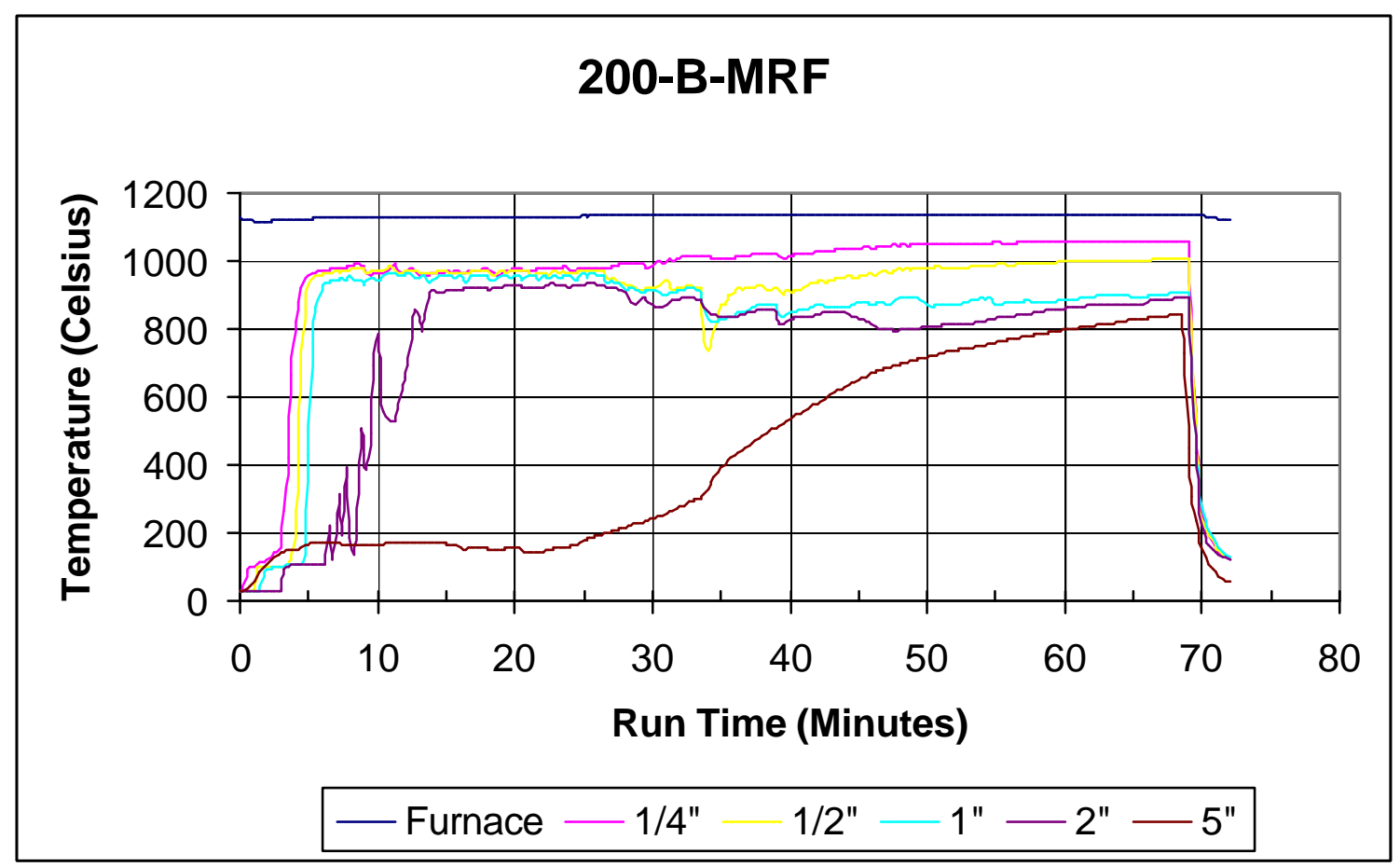


WSRC-TR-2000-00395

Page 36 of 40

Figure B-11. 131-O-MRF-R: Oxidizing Feed and Frit 131 (Repeat of 131-O-MRF)

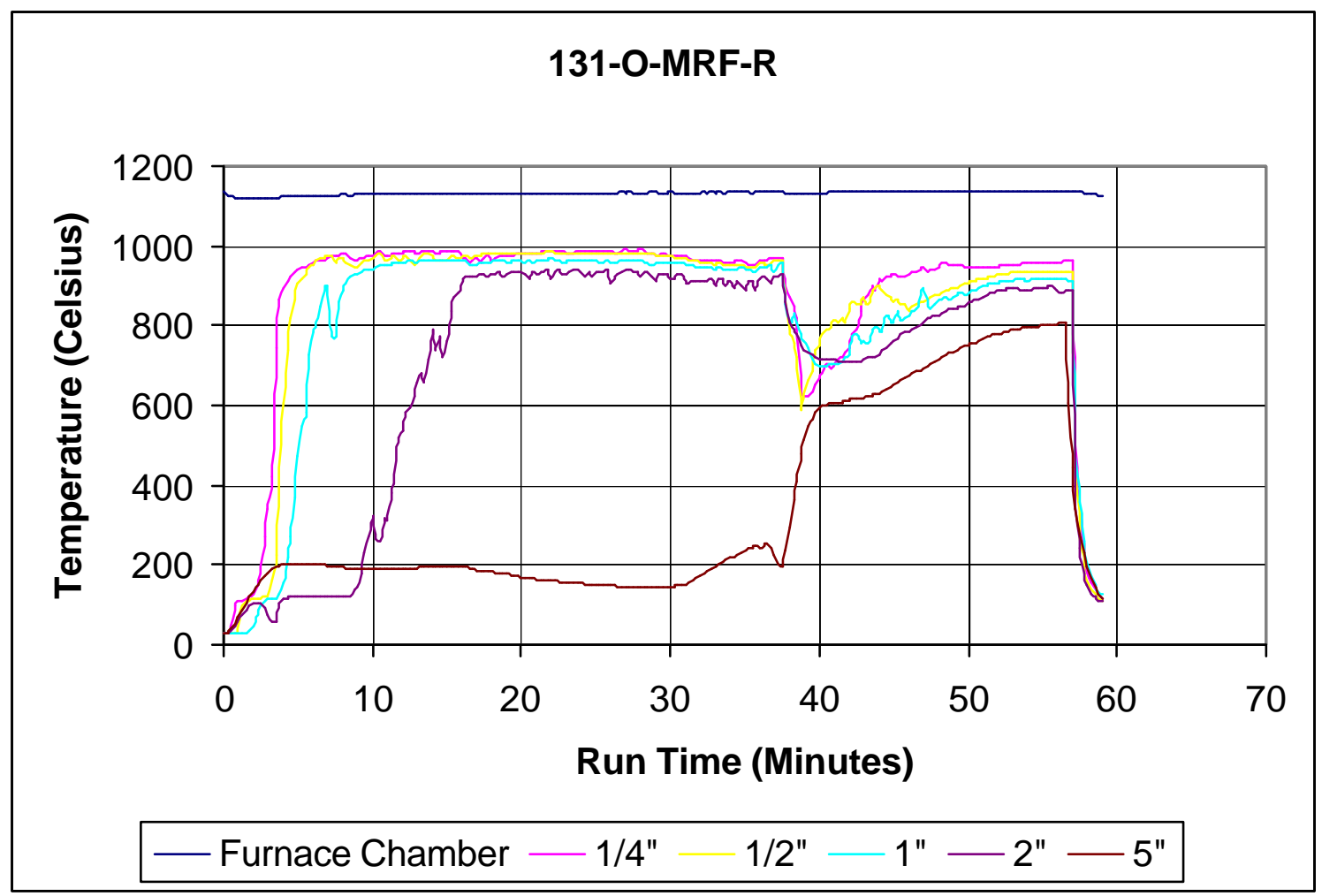

Figure B-12. 131-R-MRF: Reducing Feed and Frit 131

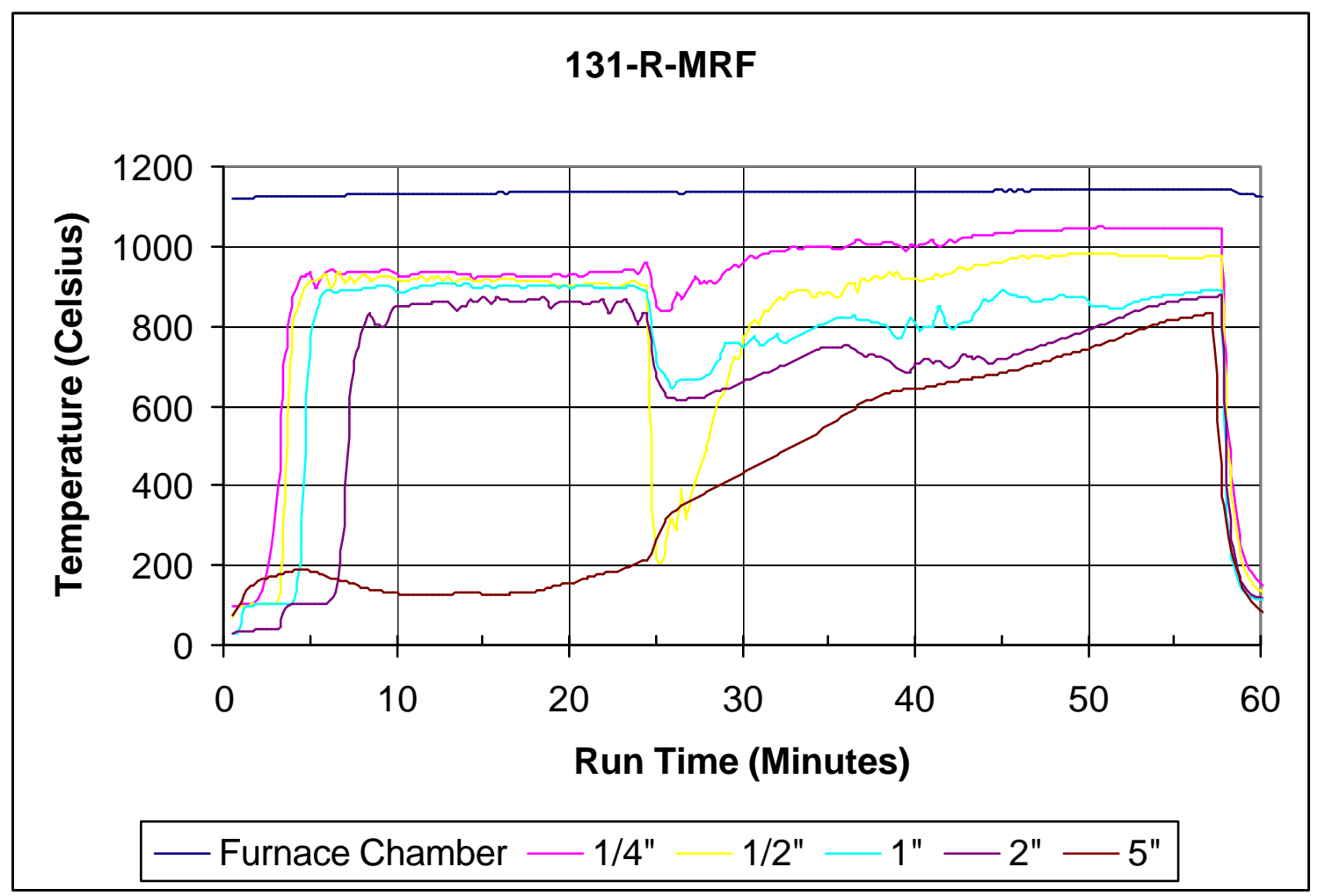


WSRC-TR-2000-00395

Page 37 of 40

Figure B-13. 200-BSLURRY-MRF: Slurry-mixed Blended Feed with Frit 200

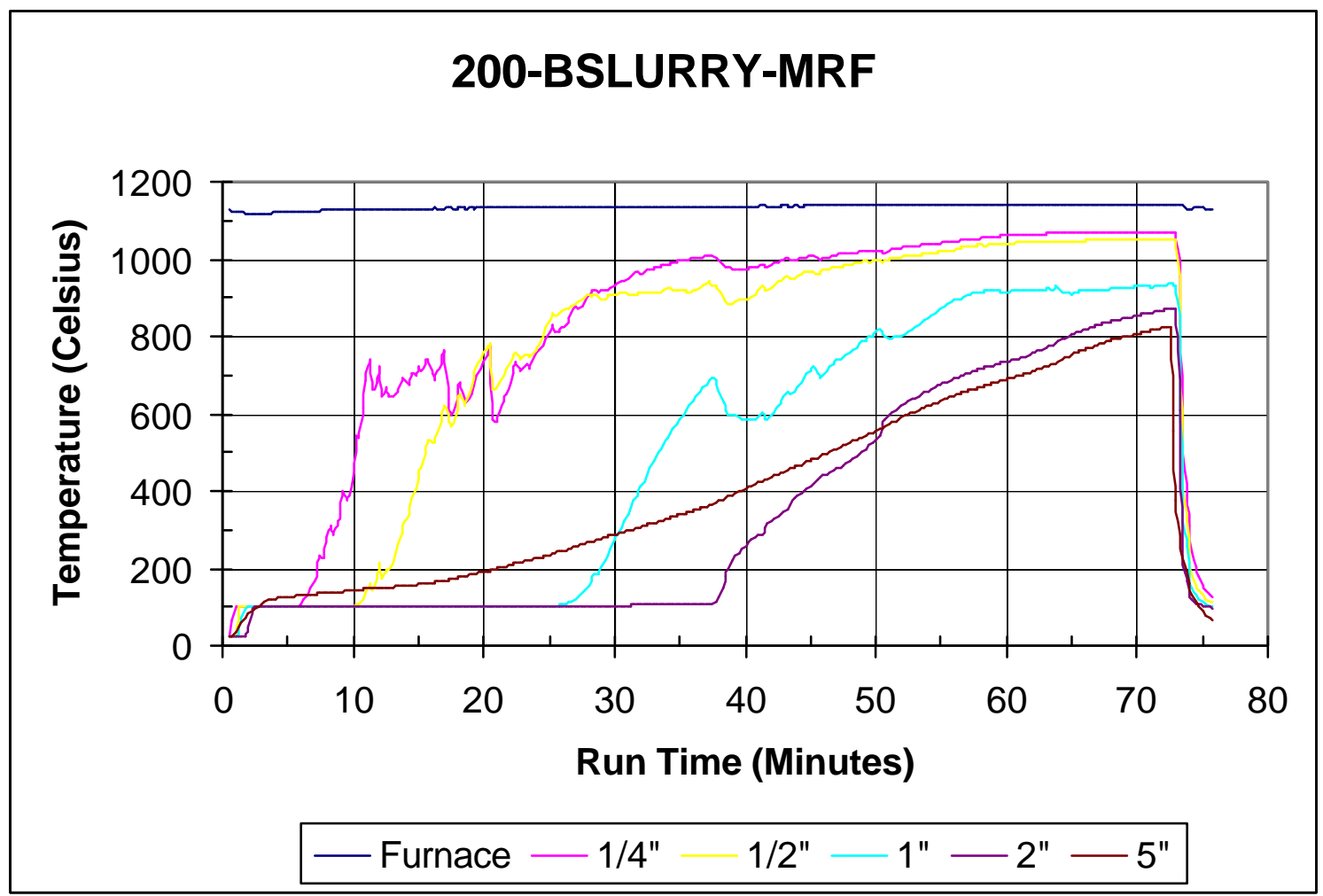

Figure B-14. 200-RSLURRY-MRF: Slurry-mixed Reducing Feed and Frit 200

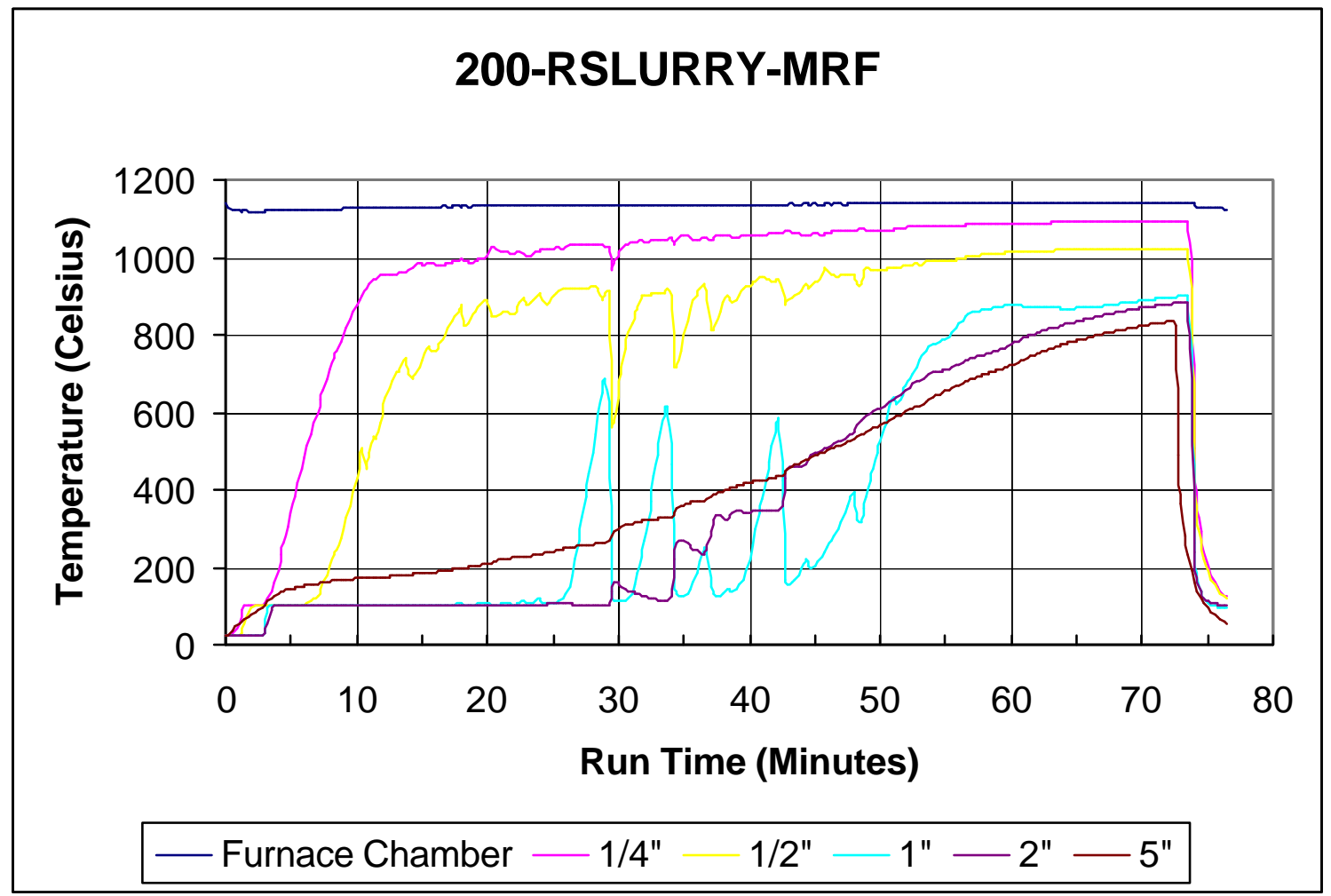


Figure B-15. 200-HMnSLURRY-MRF: High (6\%) Manganese Tank 40 SRAT Product and Frit 200

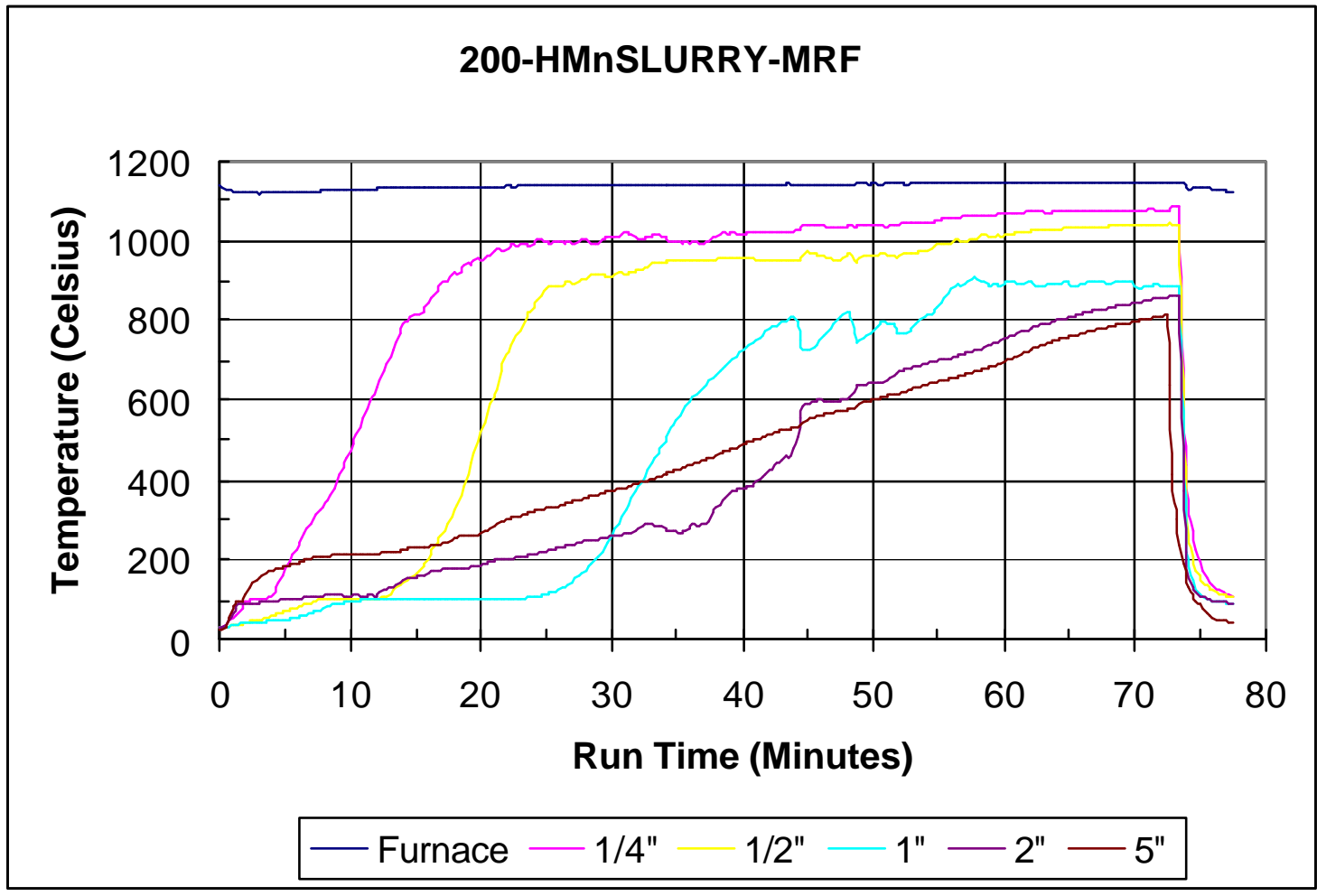

Figure B-16. 200-LMnSLURRY-MRF: Low (1.2 \%) Manganese Tank 40 SRAT Product and Frit 200

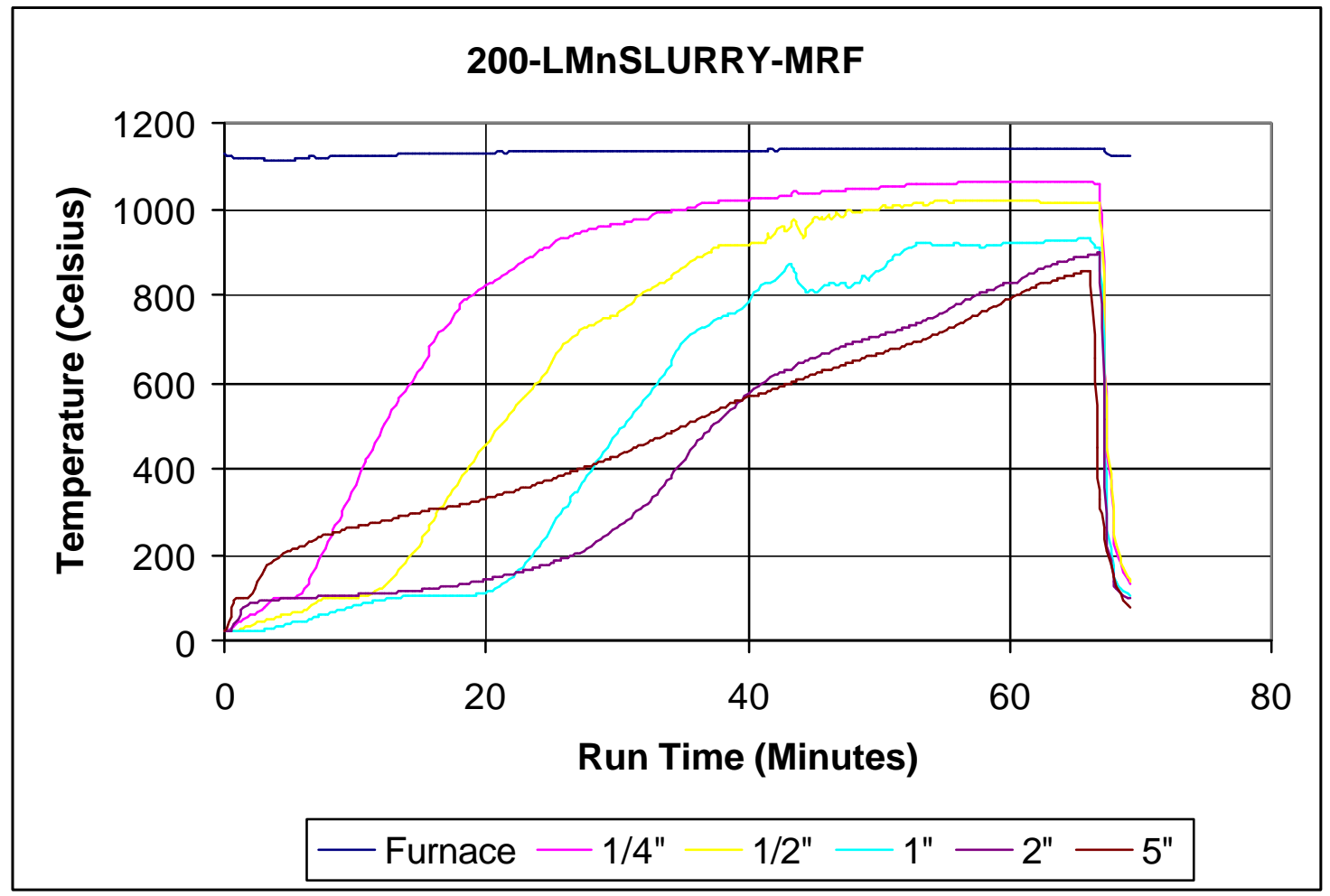


WSRC-TR-2000-00395

Page 39 of 40

\subsection{APPENDIX C: PCCS TESTING OF FRITS 165 AND 200 WITH DWPF SRAT BATCH 161}

To determine whether a frit change could be made from Frit 200 to Frit 165 in DWPF, the Product Composition and Control System (PCCS) was used. A study was made to determine whether the combination of Frit 165 and Macrobatch 2 sludge could be combined at the same waste loading and whether the operating window was large enough for DWPF operation. The results below show the operating window for Frit 165 and 200 along with liquidus and other pertinent PCCS predictions.

Table C-1: PCCS Predicted Properties for Frit 165 and Frit 200

\begin{tabular}{|l|c|c|c|c|}
\hline \multirow{2}{*}{$\begin{array}{l}\text { Predicted Property / } \\
\text { Constraint }\end{array}$} & \multicolumn{2}{|c|}{ Frit 165 } & \multicolumn{2}{c|}{ Frit 200 } \\
\cline { 2 - 5 } & Homogeneity & Liquidus & Homogeneity & Liquidus \\
\hline Sludge Oxides, wt \% & 0.265 & 0.324 & 0.265 & 0.330 \\
\hline Viscosity, poise & 45.8 & 39.0 & 84.4 & 70.6 \\
\hline $\begin{array}{l}\text { Liquidus Temperature, } \\
\text { o } \mathrm{C}\end{array}$ & 926.2 & 972.7 & 922.2 & 972.8 \\
\hline
\end{tabular}

The following is the composition of the DWPF SRAT product that was used for this analysis.

Table C-2: DWPF SRAT Batch 161 Analytical Results

\begin{tabular}{|l|l|}
\hline Analysis & ANALYTICAL RESULTS \\
\hline Total wt $\%$ solids & $20.42 w t \%(s)$ \\
\hline Calcined wt\% solids & $16.19 w t \%(s)$ \\
\hline Specific gravity & $1.131 \mathrm{spgr}$ \\
\hline Aluminum & $7.45 w t \%(s)$ \\
\hline Boron & $0.06 w t \%(\mathrm{~s})$ \\
\hline Calcium & $2.82 \mathrm{wt} \%(\mathrm{~s})$ \\
\hline Chromium & $0.13 \mathrm{wt} \%(\mathrm{~s})$ \\
\hline Copper & $0.03 \mathrm{wt} \%(\mathrm{~s})$ \\
\hline Iron & $20.19 \mathrm{wt} \%(\mathrm{~s})$ \\
\hline Potassium & $0.13 \mathrm{wt} \%(\mathrm{~s})$ \\
\hline Lithium & $0.01 \mathrm{wt} \%(\mathrm{~s})$ \\
\hline Magnesium & $1.14 \mathrm{wt} \%(\mathrm{~s})$ \\
\hline Manganese & $3.17 \mathrm{wt} \%(\mathrm{~s})$ \\
\hline Sodium & $7.16 \mathrm{wt} \%(\mathrm{~s})$ \\
\hline Nickel & $0.32 \mathrm{wt} \%(\mathrm{~s})$ \\
\hline Silicon & $1.31 \mathrm{wt} \%(\mathrm{~s})$ \\
\hline Titanium & $0.02 \mathrm{wt} \%(\mathrm{~s})$ \\
\hline Uranium & $2.60 \mathrm{wt} \%(\mathrm{~s})$ \\
\hline Zirconium & $0.06 \mathrm{wt} \%(\mathrm{~s})$ \\
\hline
\end{tabular}


WSRC-TR-2000-00395

Page 40 of 40

\section{DISTRIBUTION:}

L. M. Papouchado, 773-A

E. W. Holtzscheiter, 773-A

L. F. Landon, 704-1T

S. L. Marra, 704-1T

D. C. Witt, 704-1T

D. F. Bickford, 773-43A

D. K. Peeler, 773-43A

D. C. Koopman, 704-1T

D. P. Lambert, 704-1T

M. E. Stone, 704-1T

R. E. Eibling, 704-1T

M. F. Williams, 704-1T

J. F. Ortaldo, 704-S

W. D. Kerley, 704-S

R. E. Edwards, 704-25S

M. R. Norton, 704-27S

J. E. Occhipinti, 704-27S

J. F. Sproull, 704-30S

D. C. Iverson, 704-30S

R. J. O'Driscoll, 704-30S

Frank Woolley

John Vienna, PNNL

Joe Perez, PNNL

Pavel Hrma, PNNL

STI, 703-43A (4) 